\title{
Seismostratigraphy of the Middle St. Lawrence Esturary: A Late Quaternary Glacial Marine to Estuarine Depositional/Erosional Record
}

\section{Sismostratigraphie de l'estuaire moyen du Saint-Laurent; bilan de l'accumulation et de l'érosion glacio-marine et estuarienne au Quaternaire supérieur Seismostratigraphie des mittleren Sankt-Lorenz-Mündungsbeckens: Ein spätglazialer Beleg über
Meeres- und Mündungs-Ablagerung und Erosion}

\author{
Dan Praeg, Bruno d'Anglejan et James P. M. Syvitski
}

Volume 46, numéro 2, 1992

URI : https://id.erudit.org/iderudit/032899ar

DOI : https://doi.org/10.7202/032899ar

\section{Aller au sommaire du numéro}

\section{Éditeur(s)}

Les Presses de l'Université de Montréal

\section{ISSN}

0705-7199 (imprimé)

1492-143X (numérique)

\section{Découvrir la revue}

\section{Citer cet article}

Praeg, D., d'Anglejan, B. \& Syvitski, J. P. M. (1992). Seismostratigraphy of the Middle St. Lawrence Esturary: A Late Quaternary Glacial Marine to Estuarine Depositional/Erosional Record. Géographie physique et Quaternaire, 46(2), 133-150. https://doi.org/10.7202/032899ar

\section{Résumé de l'article}

Une fosse enfouie à socle rocheux de plus de $350 \mathrm{~m}$ de profondeur s'étend sur $100 \mathrm{~km}$ en amont du fjord du Saguenay sous le chenal du Nord. Quatre des cinq unités sismostratigraphiques quaternaires ont été identifiées à l'intérieur ou à la périphérie de la fosse. L'unité $n^{\circ} 1$ (de contact glaciaire) et des sédiments plus anciens sont peut-être aussi présents sous l'axe de cette fosse en grande partie insondée. Les unités nos 2 et 3 sont constituées d'une grande épaisseur de sédiments glacio-marins mis en place dans les eaux de la Mer de Goldthwait (>550 m) après le retrait glaciaire, vers $13 \mathrm{ka} \mathrm{BP}$; les boues de recouvrement de la couche inférieure, de 10 à $20 \mathrm{~m}$ d'épaisseur (unité $\mathrm{n}^{\circ}$ 2), témoignent d'une mise en place à proximité de la marge en recul, alors que les boues sus-jacentes de $290 \mathrm{~m}$ d'épaisseur (unité $\mathrm{n}^{\circ}$ 3) reflètent un remplissage distal du bassin. Le passage latéral à une accumulation proximale de matériel à grains grossiers de $5^{*} 260 \mathrm{~m}$ d'épaisseur (unité $\mathrm{n}^{\circ} 2$ ) est indiqué par l'élévation et le renforcement des réflecteurs vers l'entrée du Saguenay, où une marge glaciaire stable a fourni des sédiments à l'estuaire inférieur et moyen de 13 à $11 \mathrm{ka} B P$ environ. L'unité $\mathrm{n}^{\circ} 4$ correspond à des lobes de plus de $30 \mathrm{~m}$ d'épaisseur de chaque côté du chenal du Nord, témoignant d'une accumulation marginale à partir de sources fluvio-deltaïques glaciaires. L'unité $\mathrm{n}^{\circ} 5$ (sables, graviers et boues estuariennes de $=£ 30 \mathrm{~m}$ d'épaisseur) recouvre en discordance les unités glaciaires. Une surface de discordance unie témoigne d'une érosion (de $15 \mathrm{~m}$, à des profondeurs de $>150 \mathrm{~m}$ dans l'axe) par de forts courants; la topographie irrégulière de 25-50 $\mathrm{m}$ de profondeur pourrait être liée à l'abaissement des niveaux marins, vers 7-6 ka BP. 


\section{SEISMOSTRATIGRAPHY OF THE MIDDLE ST. LAWRENCE ESTUARY: A LATE QUATERNARY GLACIAL MARINE TO ESTUARINE DEPOSITIONAL/ EROSIONAL RECORD*}

Dan PRAEG**, Bruno d'ANGLEJAN and James P. M. SYVITSKI; first and third authors; Geological Survey of Canada, Atlantic Geoscience Centre, Bedford Institute of Oceanography, P. O. Box 1006, Dartmouth, Nova Scotia B2Y 4A2; second author; Department of Geological Sciences, McGill University, 3450, rue University, Montréal, Québec H3A 2 A7.

ABSTRACT A buried bedrock trough $>350 \mathrm{~m}$ deep extends $100 \mathrm{~km}$ above Saguenay Fjord beneath the North Channel of the middle estuary. Four of five regional seismostratigraphic units are recognized in and adjacent to the trough; unit 1 (glacial icecontact) and older sediments might also be present beneath the largely unpenetrated trough axis. Units 2 and 3 represent thick glacial marine sediments deposited in the $>550 \mathrm{~m}$ deep waters of the Goldthwait Sea after glacial withdrawal ca. 13 ka BP: lower draped muds $10-20 \mathrm{~m}$ thick (unit 2) suggest deposition proximal to a retreating ice margin, while upper onlapping muds $>290 \mathrm{~m}$ thick (unit 3) record distal basin-filling; lateral transition to a coarse-grained proximal wedge $\geqslant 260 \mathrm{~m}$ thick (unit 2) is indicated by unit 3 reflectors rising and strengthening towards the Saguenay entrance, where a stable icemargin ca. 13-11 ka BP supplied sediment to the lower and middle estuary. Unit 4 corresponds to lobes over $30 \mathrm{~m}$ thick on both sides of the upper North Channel, recording marginal input from glacial fluvio-deltaic sources. Unit 5 (estuarine sands, gravels and muds $\leqslant 30 \mathrm{~m}$ thick) unconformably overlies glacial units. A smooth unconformity surface records erosion (at least $15 \mathrm{~m}$, to axial depths $>150 \mathrm{~m}$ ) by strong currents; irregular relief above depths of 25-50 m might relate to relative sea levels below present ca. 7-6 ka BP. Sand bedforms (apparently inactive) occur at the estuary floor, and possibly buried beneath estuarine muds; buried bedforms would imply an early Holocene genesis. Greatest thicknesses of estuarine mud coincide with adjacent fluvial discharges. Sandy/gravelly veneers form the estuary floor in most places. Mass displacement has disturbed units 3 and 5 along the northern, and locally southern, walls of the North Channel.
RÉSUMÉ Sismostratigraphie de l'estuaire moyen du Saint-Laurent; bilan de l'accumulation et de l'érosion glacio-marine et estuarienne au Quaternaire supérieur. Une fosse enfouie à socle rocheux de plus de $350 \mathrm{~m}$ de profondeur s'étend sur $100 \mathrm{~km}$ en amont du fjord du Saguenay sous le chenal du Nord. Quatre des cinq unités sismostratigraphiques quaternaires ont été identifiées à l'intérieur ou à la périphérie de la fosse. L'unité $n^{\circ} 1$ (de contact glaciaire) et des sédiments plus anciens sont peut-être aussi présents sous l'axe de cette fosse en grande partie insondée. Les unités $n^{\text {os }} 2$ et 3 sont constituées d'une grande épaisseur de sédiments glacio-marins mis en place dans les eaux de la Mer de Goldthwait ( $>550 \mathrm{~m}$ ) après le retrait glaciaire, vers $13 \mathrm{ka} B P$; les boues de recouvrement de la couche inférieure, de 10 à 20 m d'épaisseur (unité $\mathrm{n}^{\circ} 2$ ), témoignent d'une mise en place à proximité de la marge en recul, alors que les boues sus-jacentes de $290 \mathrm{~m}$ d'épaisseur (unité $n^{\circ} 3$ ) reflètent un remplissage distal du bassin. Le passage latéral à une accumulation proximale de matériel à grains grossiers de $\geqslant 260 \mathrm{~m}$ d'épaisseur (unité $\mathrm{n}^{\circ} 2$ ) est indiqué par l'élévation et le renforcement des réflecteurs vers l'entrée du Saguenay, où une marge glaciaire stable a fourni des sédiments à l'estuaire inférieur et moyen de 13 à 11 ka BP environ. L'unité $n^{\circ} 4$ correspond à des lobes de plus de $30 \mathrm{~m}$ d'épaisseur de chaque côté du chenal du Nord, témoignant d'une accumulation marginale à partir de sources fluvio-deltaïques glaciaires. L'unite $n^{\circ} 5$ (sables, graviers et boues estuariennes de $\leqslant 30 \mathrm{~m}$ d'épaisseur) recouvre en discordance les unités glaciaires. Une surface de discordance unie témoigne d'une érosion (de $15 \mathrm{~m}$, à des profondeurs de $>150 \mathrm{~m}$ dans l'axe) par de forts courants; la topographie irrégulière de 25-50 m de profondeur pourrait être liée à l'abaissement des niveaux marins, vers 7-6 ka BP.
ZUSAMMENFASSUNG Seismostratigraphie des mittleren Sankt-Lorenz-Mündungsbeckens: Ein spätglazialer Beleg über Meeresund Mündungs-Ablagerung und Erosion. Vergrabenes anstehendes Gestein erstreckt sich über $100 \mathrm{~km}$ in $>350 \mathrm{~m}$ Tiefe oberhalb des Saguenay-Fjords unter dem Nord-Kanal des mittleren Mündungsbeckens. Vier von fünf regionalen seismostratigraphischen Einheiten sind in und neben dem Trog erkannt worden; Einheit 1 (glazialer Eiskontakt) und ältere Sedimente könnten auch unter der weitgehend nichtergründeten Trog-Achse vorhanden sein. Die Einheiten 2 und 3 bestehen aus dicken glazialen marinen Sedimenten, welche in dem <550 m tiefen Wasser des GoldwaithMeeres nach dem glazialen Rückzug um etwa 13 ka v.u.Z. abgelagert wurden: tiefer gelegener, locker angelagerter Schlamm von 10-20 m Dicke (Einheit 2) läßt auf eine Ablagerung nahe dem zurückweichenden Eissaum schließen, während höhergelegener Schlamm von $>290$ m Dicke (Einheit 3) distale BeckenFüllung belegt; eine laterale Überleitung zu einem grobkörnigen proximalen Keil von $\geqslant 260 \mathrm{~m}$ Dicke (Einheit 2) wird durch die Anhebung und Verstärkung der Einheit 3 Reflektoren zum Eingang des Saguenay hin angezeigt, wo ein stabiler Eissaum etwa 13-11 ka v.u.Z. Sediment zum unteren und mittleren Mündungsbecken brachte. Einheit 4 entspricht über $30 \mathrm{~m}$ dicken Loben beiderseits des oberen Nord-Kanals, und belegt eine Anlagerung von glazialen Fluß-Delta-Quellen am Rand. Einheit 5 (Mündungsbecken-Sand, Kies und Schlamm $\leqslant 30 \mathrm{~m}$ cick) überlagert in Diskordanz die glazialen Einheiten. Eine glatte Diskoranz-Oberfläche belegt eine Erosion (mindestens $15 \mathrm{~m}$, bis zu Tiefen von $>150 \mathrm{~m}$ in der Achse) durch starke Strömungen; das unregelmäßige Relief über den Tiefen von 25-50 m könnte mit relativen Meeresniveaus, die etwa um 7-6 ka v.u.Z. unter den gegenwärtigen lagen, zusammenhängen.

\footnotetext{
* Geological Survey of Canada Contribution No. 35790

** Present address: Grant Institute of Geology and Geophysics, University of Edinburgh, West Mains Road, Edinburgh, Scotland EH9 3JW, United Kingdom.

Manuscrit reçu le 13 mars 1991; manuscrit révisé accepté le $1^{\text {er }}$ octobre 1991
} 


\section{INTRODUCTION}

The St. Lawrence Estuary has undergone dramatic changes in environment during the last 15,000 years: it has been occupied by glacial ice of the Laurentide Ice Sheet, it is thought to have been transgressed by a calving bay marking glacial withdrawal, and it has been up to $200 \mathrm{~m}$ deeper as a marine branch of the deglacial Goldthwait Sea (Dyke and Prest, 1987). At present it is one of the largest estuaries in the world, a major conduit for water and sediment from continental North America to the Atlantic (El-Sabh and Silverberg, 1990). It also includes one of the most active seismic zones in eastern Canada, in the Charlevoix region of the middle estuary (Adams and Basham, 1989).

The late Quaternary sedimentation history of the Estuary is a product of the changing sediment flux and oceanographic conditions concomittant on the withdrawal of glacial ice and the transition from open (glacial) marine to estuarine conditions. This paper focuses on the history of the middle estuary, primarily the North Channel (Fig. 1). We use acoustic data to examine the Quaternary sediments that lie in and adjacent to a deep trough underlying the North Channel. The sediments are divided into seismic units with reference to a regional seismostratigraphic framework recently proposed for the northwest Gulf and the Estuary of the St. Lawrence (Syvitski and Praeg, 1989). The seismostratigraphic sequence can be related to lithostratigraphies from the shores of the estuary, and so to chronostratigraphic reconstructions of the Late Wisconsinan deglaciation (e.g. Dyke and Prest, 1987). The continuous vertical and horizontal coverage afforded by seismic profiles allows an improved understanding of the large-scale geometry and relationships of these glacial to postglacial sediments, and so of the depositional and erosional events they record.
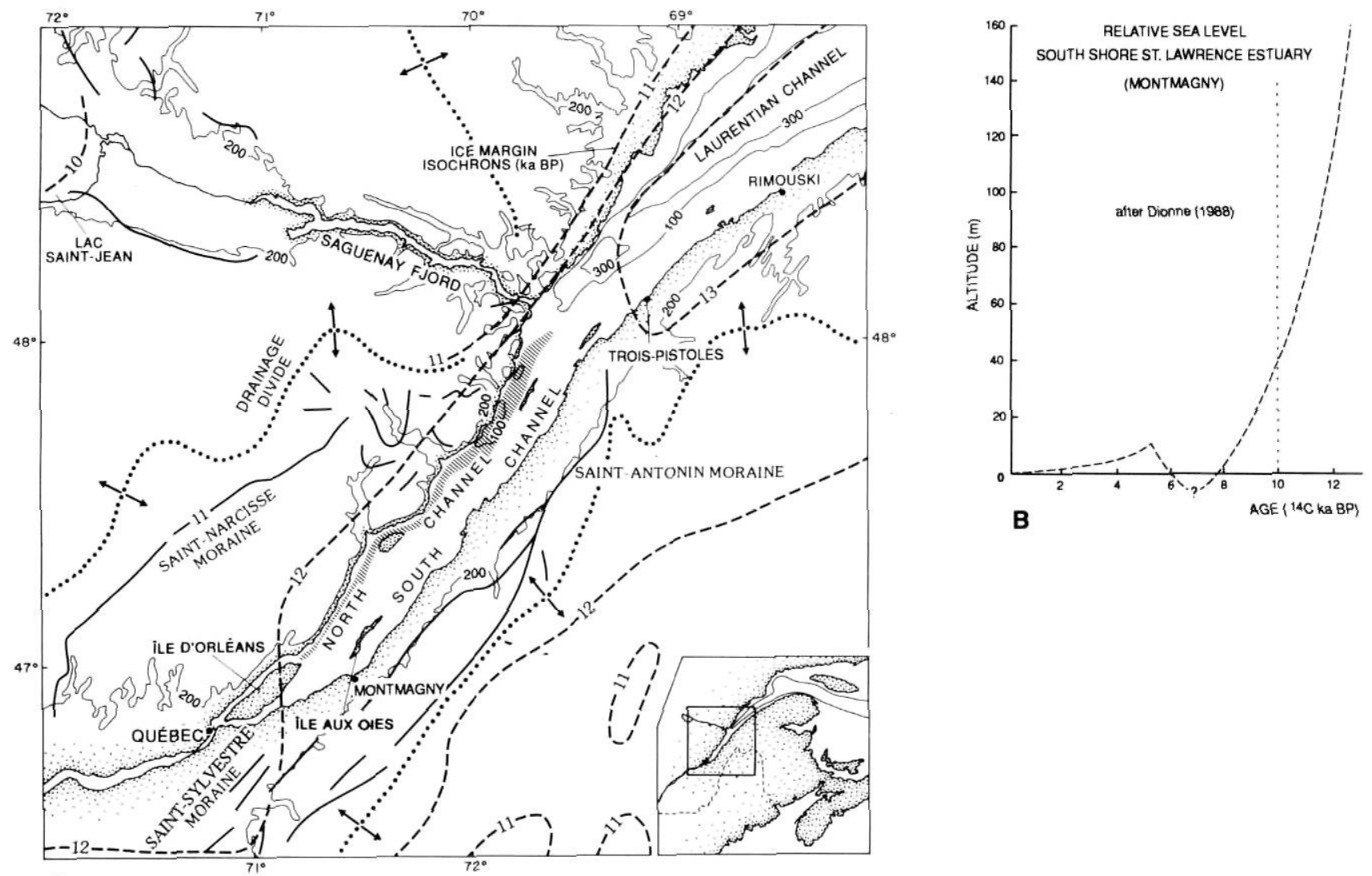

A

FIGURE 1. A) Summary of Late Wisconsinan deglaciation of the study area (from Dyke and Prest, 1987; Saint-Sylvestre Moraine from Parent and Ochietti, 1988). The middle St. Lawrence Estuary extends some $200 \mathrm{~km}$ between Saguenay Fjord and Québec; depths greater than $30 \mathrm{~m}$ are confined to parts of the North Channel (stippled), separated from the Laurentian Channel in the lower estuary by a sill with limiting depths of $45 \mathrm{~m}$ (see Fig. 2). Topographic/bathymetric contours in metres. B) Relative sea level history subsequent to glacial withdrawal on the south shore (after Dionne, 1988: $<10$ ka BP from his Figure $7,>10$ ka from his Table 2 following trends of Locat, 1977 and Lortie and Guilbault, 1984 shown in Figure 7); relative sea levels on the north shore were up to $200 \mathrm{~m}$ above present (Rondot, 1974).
A) Sommaire de la déglaciation du Wisconsinien supérieur dans la région à l'étude (selon Dyke et Prest, 1987; Moraine de Saint-Sylvestre selon Parent et Occhietti, 1988). L'estuaire moyen du Saint-Laurent s'étend sur près de $200 \mathrm{~km}$ entre le fjord du Saguenay et Québec; les profondeurs de plus de $30 \mathrm{~m}$ se limitent à certaines régions du chenal du Nord (hachures), séparées du chenal Laurentien, dans l'estuaire moyen, par un seuil de $45 \mathrm{~m}$ (voir fig. 2). Courbes de niveau et bathymétriques en mètres. B) Évolution du niveau marin relatif depuis le retrait glaciaire, sur la côte sud (d'après Dionne, 1988: depuis $10 \mathrm{ka} B P$ selon sa fig. 7 , avant $10 \mathrm{ka} \mathrm{BP}$ selon son tabl. 2 fondé sur les arcs de Locat, 1977 et de Lortie et Guilbault, 1984, fig. 7); les niveaux marins relatifs sur la Côte Nord ont été jusqu'à $200 \mathrm{~m}$ au-dessus du niveau actuel. 


\section{PHYSICAL SETTING}

The middle estuary, as proposed by Dionne (1963), extends some 200 km between Québec and Saguenay Fjord (Fig. 1a); its $20 \mathrm{~km}$ of width joins the western and eastern Lowlands of the St. Lawrence, and separates the Appalachian Mountains and Uplands to the south from the Laurentian Highlands of the Precambrian Shield to the north (Bostock, 1970). The south shore rises to elevations locally over $500 \mathrm{~m}$, with relief dominated by shore-parallel ridges and depressions reflecting the eroded structural trends of the Appalachian Province; the north shore rises more steeply to elevations locally over $1000 \mathrm{~m}$, and the crystalline rocks of the Grenville Province are dissected by shore-transverse valleys with 100's of metres relief (Fig. 1a). Such valleys occur along the north shore of the St. Lawrence seaward to the Gulf; Saguenay Fjord is a large, submerged example, a $90 \mathrm{~km}$ long, steep-sided, overdeepened (axial basins) trough with water depths over $300 \mathrm{~m}$ and depths to bedrock locally over 1 km (Syvitski and Praeg, 1989; Praeg and Syvitski, 1991).
The lower estuary below Saguenay Fjord contains the head of the Laurentian Channel, an overdeepened trough (water depths over $300 \mathrm{~m}$, depths to bedrock over $700 \mathrm{~m}$; Syvitski and Praeg, 1990) which extends some $1200 \mathrm{~km}$ seaward to the continental margin (Fig. 1a). The middle estuary is mostly less than $30 \mathrm{~m}$ deep, characterized by a complex of shore-parallel channels and shoals including islands of Appalachian bedrock. Greater depths are present in the North Channel, which is separated from the Laurentian Channel by a sill with limiting depths of $45 \mathrm{~m}$ (Fig. 2). Two main basins are present in the North Channel: the Île aux Lièvres basin with depths locally over $150 \mathrm{~m}$, and the Île aux Coudres basin with depths locally over $90 \mathrm{~m}$, separated by a sill adjacent to English Bank with limiting depths of $35 \mathrm{~m}$ (Fig. 2).

The asymmetrical cross-profile of the middle estuary strongly influences the tidally dominated circulation patterns: flood flows dominate the North Channel, versus ebb flows in the south channel. Hydrographic charts indicate flood and ebb current velocities of up to 7 knots $(3.5 \mathrm{~m} / \mathrm{s})$ in the narrow pas-
FIGURE 2. Type and distribution of acoustic survey lines in the study area (see text for data sources). The North Channel includes the Île aux Coudres and Île aux Lièvres basins (stippled), separated by a $35 \mathrm{~m}$ sill between La Malbaie and English Bank. Topography and bathymetry from Natural Resource Series maps 15179-A and 15188-A (1972).

Les types de relevés acoustiques et leur distribution (voir le texte pour les sources). Le chenal du Nord comprend les bassins de l'île aux Coudres et de l'île aux Lièvres (hachures), séparés par un seuil de $35 \mathrm{~m}$ entre La Malbaie et le banc des Anglais. Topographie et bathymétrie selon les cartes 15179-A et 15188-A du Service hydrographique canadien (1972).

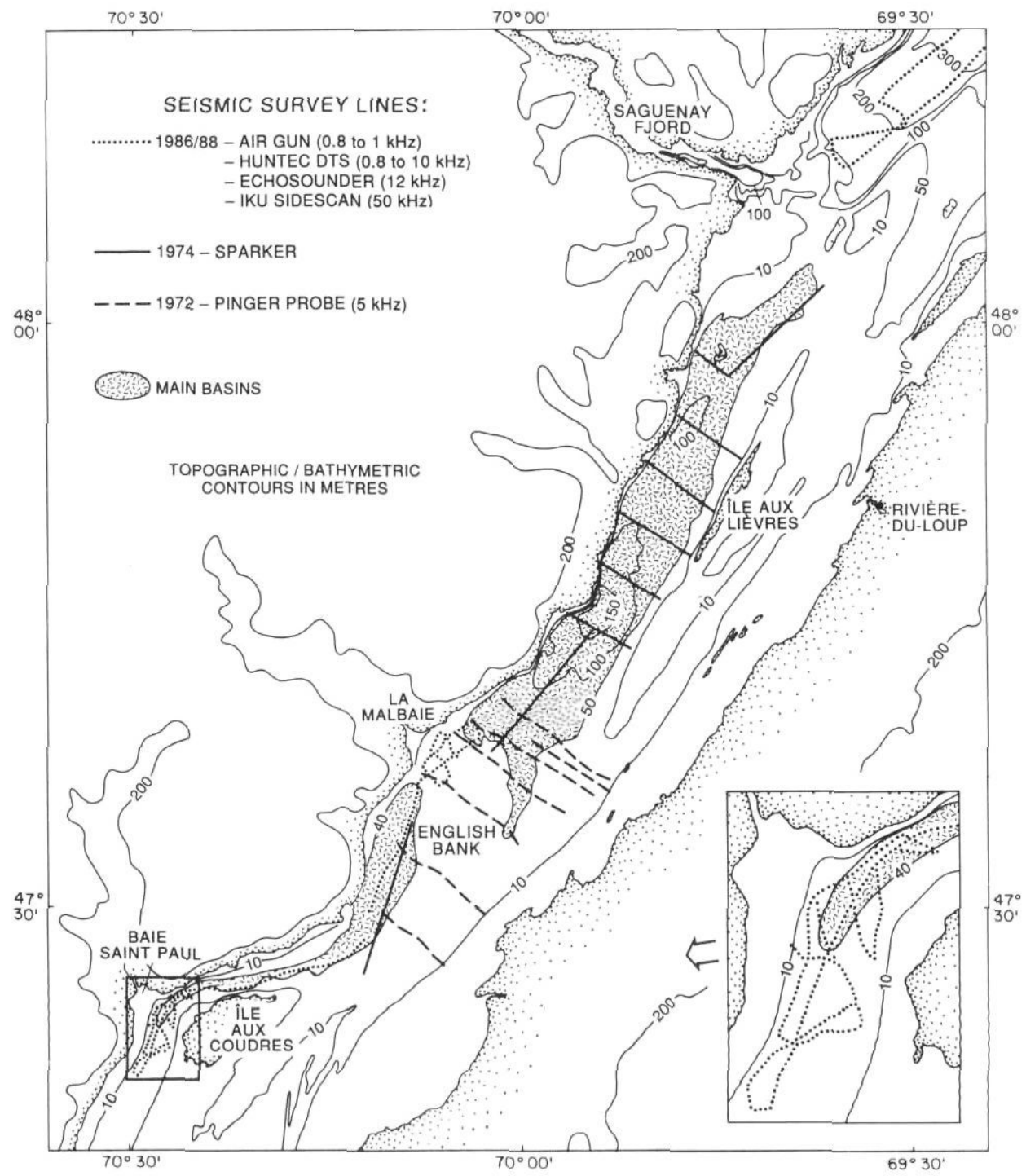

Géographie physique et Quaternaire, 46(2), 1992 
sage between Île aux Coudres and the north shore. A turbidity maximum zone extends between île d'Orléans and île aux Coudres, ending downstream and along the south shore in a sharp front; it is maintained by the combined effects of estuarine circulation, tidal and wave resuspension from shallower depths, and material exchanges with extensive tidal flats and marshes on both shores (see d'Anglejan, 1990). Waters which are both fresher and more turbid exit along the south shore into the lower estuary, after mixing with the Saguenay outflow.

\section{LATE QUATERNARY DEGLACIAL HISTORY}

The Laurentide Ice Sheet was receding from a maximum position in the Gulf of St. Lawrence by 14 ka BP (Dyke and Prest, 1987). Evidence for reversal of ice flow directions along the south shore of the St. Lawrence Estuary is argued to record the migration of a calving margin up the Estuary (Thomas, 1977; LaSalle et al., 1977; Chauvin et al., 1985; Lowell et al., 1990), which separated an Appalachian ice mass to the south from Laurentide ice to the north along either shore of the invading Goldthwait Sea (Dionne, 1977). The marine invasion reached the La Malbaie/Baie-Saint-Paul region of the middle estuary by 12.8-12.5 ka BP (LaSalle et al., 1977; Dionne, 1977). Appalachian ice stabilized and formed the Saint-Antonin Moraine along the southern margin of the Goldthwait Sea (Lee, 1962) sometime between 12.5 and 13 ka BP (Fig. 1a). Chauvin et al. (1985) argued that the calving margin reached its limit at Québec as Laurentide ice stabilized on the south shore; Parent and Occhietti (1988) specified the Saint-Sylvestre Moraine (Fig. 1a) as recording the margin of an ice lobe that separated the marine waters from glacial lakes Candona and predecessors in the St. Lawrence lowlands, subsequent to $c a$. $12.4 \mathrm{ka}$.

The ice barrier was breached ca. $12 \mathrm{ka} \mathrm{BP}$ (Parent and Occhietti, 1988), allowing marine waters to enter the St. Lawrence lowlands as the Champlain Sea (Gadd, 1971). Appalachian ice had withdrawn from the Goldthwait Sea by $12 \mathrm{ka} \mathrm{BP}$, and was subsequently reduced to residual ice masses (Fig. 1a). Laurentide ice stabilized along the SaintNarcisse Moraine (Hardy, 1970; Rondot, 1974; Poulin, 1976) ca. $11 \mathrm{ka} \mathrm{BP}$ (Fig. 1a), remaining in partial contact with the Goldthwait Sea via the valleys of the north shore and at the entrance to Saguenay Fjord. The ice margin rapidly withdrew to Lac Saint-Jean at the head of the Saguenay by $10 \mathrm{ka} \mathrm{BP}$ (Fig. 1a), and finally withdrew from the Laflamme Sea occupying the Saguenay region by $8.4 \mathrm{ka}$ BP (Dyke and Prest, 1987).

Goldthwait Sea levels up to 190-200 m above present are recorded on the north shore near Québec (Goldthwait, 1933), and in the Baie-Saint-Paul/La Malbaie area (Rondot, 1974; Poulin, 1976; Dionne, 1977). Sea level curves from the south shore of the middle and lower estuary (Elson, 1969; Locat, 1977; Lortie and Guilbault, 1984; Dionne, 1988) indicate a marked decrease in rates of emergence (Fig. $1 \mathrm{~b}$ ), from $3.2 \mathrm{~cm} / \mathrm{a}$ between 13 and $9 \mathrm{ka}$ BP ( $85 \%$ emergence), to less than $0.1 \mathrm{~cm} / \mathrm{a}$ at present. Dionne $(1988,1990)$ showed that emergence was not continuous in the middle estuary, but included sea levels at least $5 \mathrm{~m}$ lower than present between 7 to $6 \mathrm{ka} \mathrm{BP}$, an 8 to $10 \mathrm{~m}$ transgression between 5.8 to $4.4 \mathrm{ka} \mathrm{BP}$, and sea levels near present since ca. $3 \mathrm{ka} \mathrm{BP}$ (Fig. 1b).

\section{METHODS}

Six types of analog acoustic records were available from three different surveys, totalling about $300 \mathrm{~km}$ of lines (Fig. 2). Multi-parameter surveys in 1986 and 1988 (Praeg et al., 1987; Syvitski, 1988) collected both lower frequency (deeper penetration) and higher frequency (greater resolution) singlechannel seismic reflection profiles, as well as sidescan sonar imagery (Fig. 2; see Syvitski and Praeg, 1989, for details of survey methods). These records were used to establish the seismostratigraphic units, which were then extended using lower frequency sparker profiles collected in 1974 (d'Anglejan and Brisebois, 1978), and higher frequency pinger profiles collected in 1972 (d'Anglejan and Brisebois, 1974). Survey lines were positioned by radar fixes, supplemented in 1986 by continuously recorded LORAN-C fixes; accuracy is considered to be better than $\pm 100 \mathrm{~m}$.

Thicknesses measured from the different seismic records are accurate to $\pm 1 \mathrm{~m}$, but resolution (minimum thickness measurable) varies from $\leqslant 5 \mathrm{~m}$ for the 1974 sparker lines, to $\leqslant 1 \mathrm{~m}$ for the 1986/88 multi-parameter lines and the 1972 pinger lines (although the latter afford less penetration). Throughout this paper travel-times are reported as thicknesses in metres, for conceptual ease, calculated using an assumed velocity of $1.5 \mathrm{~km} / \mathrm{s}$ (approximate velocity of sound in water). Actual unconsolidated sediment velocities may vary from 1.5 to $2.0 \mathrm{~km} / \mathrm{s}$ (e.g. Hamilton, 1985), so the reported thicknesses represent minimum estimates. Seismostratigraphic units are successive intervals that can be recognized and traced based on distinctive acoustic attributes (stratification and tone), bedding styles, and/or unit geometry, and which may display lateral facies variability in these characteristics (see Syvitski and Praeg, 1989).

\section{BURIED TROUGH}

A strong reflector forms the base of the Quaternary sequence discussed below; it constitutes acoustic basement (with one exception, below), and is considered to represent bedrock. It is recognized across the North Channel adjacent to Baie-Saint-Paul (Fig. 3), and along the southern, and locally northern, margin of the North Channel to seaward (Figs. 5-7), outlining a buried trough and bordering subsurface ridges (Fig. 4b). The ridges are consistent with the presence of Paleozoic metasedimentary rocks of the Appalachian Province south of Logan's Line (Fig. 4, inset). Similar subsurface bedrock ridges, associated with islands and shoals, are indicated from seismic data described by Simard (1971) for the south side of the middle estuary upstream from île aux Coudres (Fig. 1a). In the lower estuary, both high-relief Appalachian bedrock along the south shore and lower-relief Precambrian bedrock along the north shore correspond to acoustic basement, while intervening Ordovician Platform sedimentary strata correspond to inclined reflectors truncated by an unconformity (Loring and Nota, 1973; Syvitski and Praeg, 1989).

The axis of the buried trough is observed only adjacent to Baie-Saint-Paul, where penetration of the basal reflector is indicated by at least one underlying, apparently truncated, inclined reflector (Fig. 3c). The basal reflector remains strong despite the presence of the underlying event, and is locally relatively steep, neither of which might be expected over a pocket of 
FIGURE 3. Interpreted acoustic transects (1986 air gun profiles and sidescan sonar imagery; cf. Fig. 2) across the île aux Coudres basin adjacent to Baie-Saint-Paul: a) note the ' $v$-shaped' cross-section of each of the two channels crossed (cf. Fig. 4b); a lower draped interval (unit 2) may be more extensive; the contact between units 3 and 4 mirrors the relief at the base of unit 3 , suggesting that it is largely conformable; unit 4 is part of a lobe that extends from Baie-Saint-Paul (cf. Fig. 7); sidescan imagery shows truncated bedding planes at the exposed surface of unit 3 , in association with both irregular and smooth relief (cf. Fig. 7). b) a unit 5 sand lens $20 \mathrm{~m}$ thick, capped by bedforms, overlies unit 3 ; the sidescan image shows truncated unit 3 bedding planes (cf. Fig. 7). c) an apparently truncated reflector below the basal reflector may record the presence of Ordovician sedimentary strata beneath the North Channel; the lower draped interval (unit 2), which may also be present to the left, is onlapped by unit 3 reflectors; an irregular unconformity surface is evident at the estuary floor (cf. Fig. 7). BR = basal reflector/bedrock. Vertical scales based on an assumed velocity of $1.5 \mathrm{~km} / \mathrm{s}$.

Interpretation des profils acoustiques (profils par canon à air et relevés par sonar à balayage latéral, voir fig. 2) au-dessus du bassin de l'île aux Coudres, près de BaieSaint-Paul. a) Noter le profil en $V$ des deux chenaux traversés (voir fig. 4b); l'intervalle inférieur de recouvrement (unité $n^{\circ} 2$ ) pourrait être plus étendu; le contact entre les unités $n^{\text {os }} 3$ et 4 reproduit le relief à la base de l'unité $n^{\circ} 3$, indiquant ainsi sa concordance; l'unité $n^{\circ} 4$ constitue un segment du lobe qui s'étend depuis Baie-Saint-Paul (voir fig. 7); le relevé par sonar latéral montre des plans de stratification tronqués associés à la topographie irrégulière ou lisse (voir fig. 7). b) Une lentille de sable (unité $n^{\circ} 5$ ) de 20 m d'épaisseur, surmontée par des dunes, recouvre l'unité $n^{\circ} 3$ (voir fig. 7). c) Un réflecteur, apparamment tronqué, situé sous le réflecteur de base pourrait indiquer la présence de couches sédimentaires ordo-

unconsolidated sediment. Sedimentary strata of the Ordovician Platform overlie Precambrian rocks in the valleys of the north shore, including Baie-Saint-Paul (Fig. 4, inset), and it has been speculated that such strata also underlie the North Channel (e.g. Sanford et al., 1979).

The axis of the buried trough adjacent to Baie-Saint-Paul has fluvial characteristics: it deepens steadily seaward, from $125 \mathrm{~m}$ to over $250 \mathrm{~m}$ (average gradient $0.7^{\circ}$ ); there are two tributaries, and some cross-sections appear v-shaped (Figs. 3a, 4b). To seaward, depths along the south wall of the trough exceed $350 \mathrm{~m}$ near La Malbaie, and $150 \mathrm{~m}$ in the Île aux Lièvres basin; a possible axial depth of $350 \mathrm{~m}$ adjacent to $\mathrm{La}$

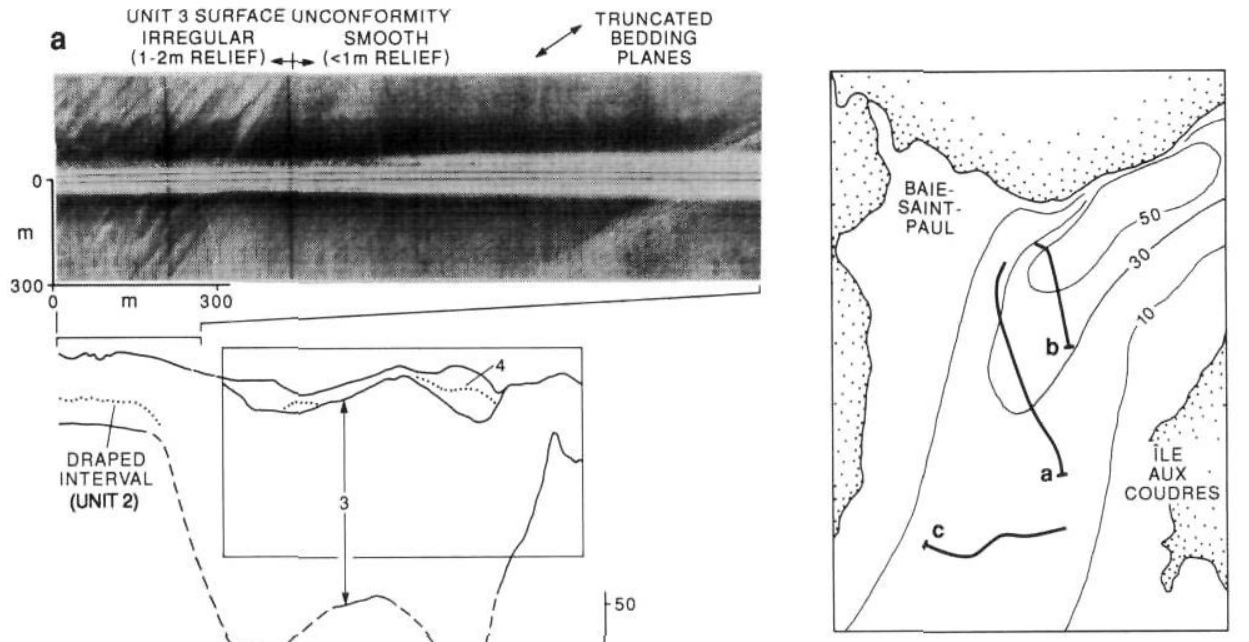

C
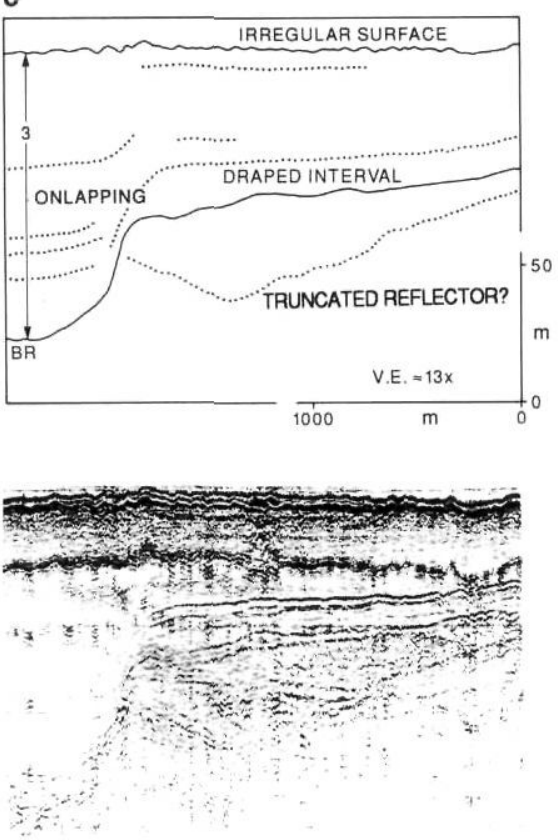

viciennes sous le chenal du Nord; l'intervalle inférieur de recouvrement (unité $n^{\circ} 2$ ), qui pourrait peut-être se prolonger vers la gauche, est surmonté par les réflecteurs de l'unité $n^{\circ} 3$; une surface de discordance irrégulière est bien visible sur le fond de l'estuaire (voir fig. 7). BR: réflecteur de base/socle rocheux. Échelles verticales fondées sur une vitesse nominale de $1,5 \mathrm{~km} / \mathrm{s}$.

Malbaie would indicate an enclosed bedrock basin beneath the île aux Coudres basin (Fig. 4b). Gradients in excess of $10^{\circ}$ are observed on both walls of the trough adjacent to La Malbaie (e.g. Fig. 5); in the Île aux Lièvres basin, gradients up to $5^{\circ}$ are observed on the south wall (e.g. Fig. 6b), while bathymetric gradients up to $15^{\circ}$ on the north wall must primarily reflect bedrock relief. The distance between the south and north walls of the trough widens steadily seaward, anticipating the widening of the Laurentian Channel and its bedrock trough in the lower estuary. There is a gap in seismic coverage at the entrance to the Saguenay (Fig. 2), but data from the lower estuary suggest the sill separating the Laurentian and North Channels 
FIGURE 4. A) Combined thickness of units 2 and 3 , which volumetrically dominate the sediment sequence. B) Depth to the base of units 2 and 3 (= depth to bedrock) from present sea level; a deep trough is evident beneath the North Channel (cf. Fig. 2), with subsurface ridges to the south; the trough axis has fluvial characteristics between Île aux Coudres and BaieSaint-Paul (inset); the axis is not recognized on seismic profiles to seaward, although a possible axial depth of $\geqslant 350 \mathrm{~m}$ is recorded off $\mathrm{La}$ Malbaie; the trough is considered an extension of the bedrock trough of the Laurentian Channel in the lower estuary. Thicknesses based on an assumed velocity of $1.5 \mathrm{~km} / \mathrm{s}$.

A) Épaisseurs combinées des unités $n^{\text {os }} 2$ et 3 , dont le volume domine la séquence sédimentaire; B) Profondeur, à partir du niveau marin actuel, jusqu'à la base des unités $n^{\text {os }} 2$ et 3 (profondeur jusqu'au socle rocheux); une fosse profonde apparaît sous le chenal du Nord (voir fig. 2), ainsi que des crêtes en marge, vers le sud; l'axe de la fosse présente un caractère fluvial entre l'île aux Coudres et Baie-Saint-Paul (carton); l'axe de la fosse n'est pas identifiable sur les profils sismiques vers l'aval, sauf une profondeur probable de $>350$ enregistrée devant La Malbaie; la fosse est considérée comme un prolongement de la fosse à socle rocheux du chenal Laurentien dans le bas estuaire. Épaisseurs fondées sur une vitesse nominale de $1,5 \mathrm{~km} / \mathrm{s}$.

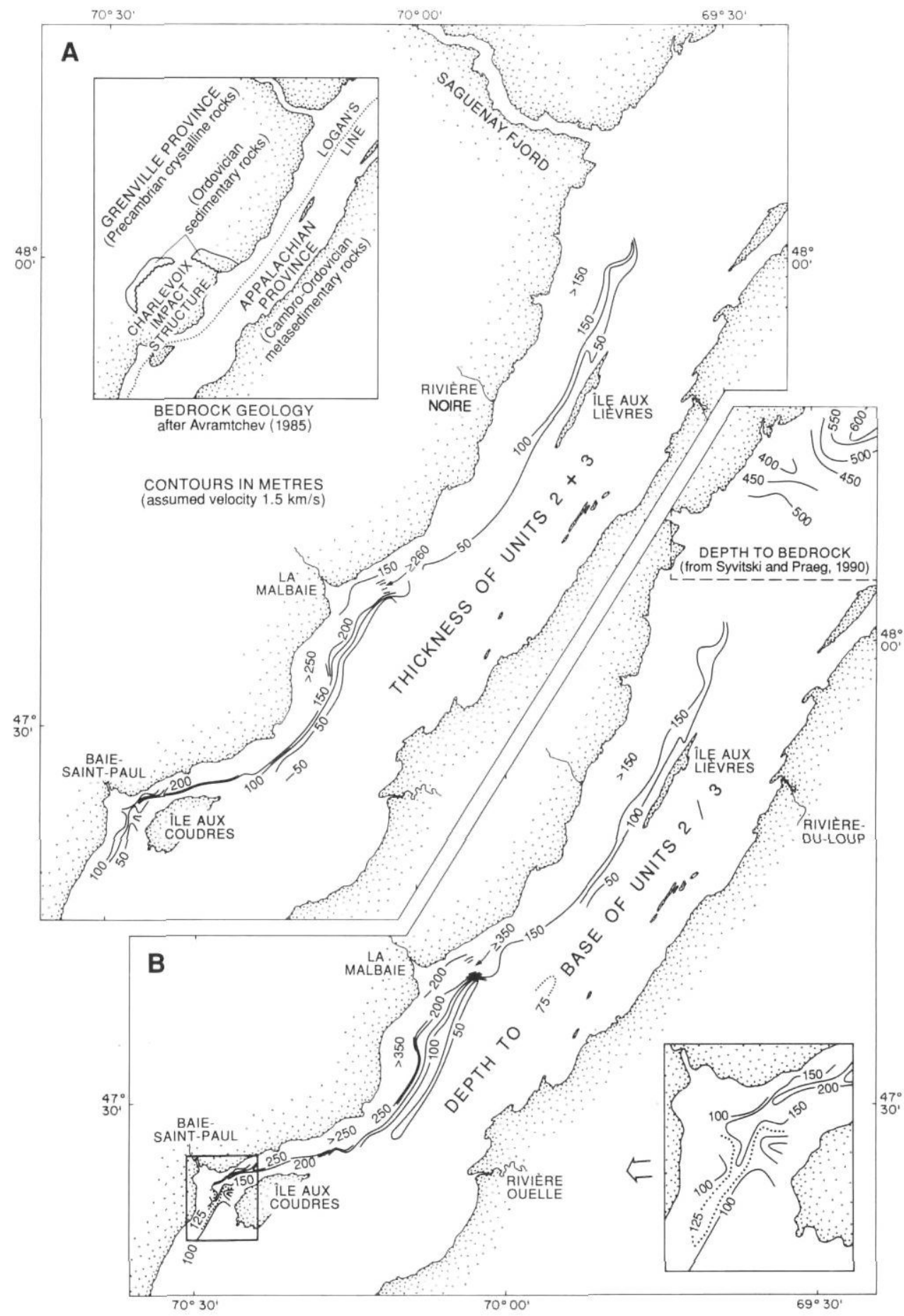

represents a thick accumulation of sediment, with depths to bedrock $>500$ m on either side of a 425 m bedrock sill (Fig. 4b). The trough beneath the North Channel is therefore considered an extension of the Laurentian bedrock trough, some $100 \mathrm{~km}$ above the Saguenay to Baie-Saint-Paul.

The steep-sided, overdeepened character of the Laurentian Channel has long invited speculation that it is a glacially excavated feature, located probably along earlier fluvial and fundamentally along ancient structural lines (Shephard, 1931; Loring and Nota, 1973). These 'glacial' characteristics are representative of the underlying bedrock trough in the lower estuary
(Syvitski and Praeg, 1990), and apparently in the middle estuary, below 'fluvial' characteristics at the head of the trough adjacent to Baie-Saint-Paul (Fig. 4b). Transverse valleys along the north shore of the St. Lawrence Estuary and Gulf are also troughs of steep-sided glacial character (e.g. Sala and Long, 1989), known to be overdeepened at least in the case of Saguenay Fjord (Praeg and Syvitski, 1991). The upstream limit of these valleys at Baie-Saint-Paul (Fig. 1a) coincides with the head of the buried bedrock trough, defining the edge of a largescale zone of glacial erosion along troughs in and adjacent to the eastern St. Lawrence Lowlands. More subdued relief in the 
western Lowlands has been interpreted to reflect long-term areal glacial erosion or deposition (Sugden, 1978); deposits of glaciations and interglaciations predating the last have been preserved throughout the area, including locally on the north shore of Île aux Coudres (Occhietti and Clet, 1989). The adjacent bedrock morphology at the head of the buried trough might represent pre-glacial fluvial relief, preserved or little-modified during subsequent glaciations.

\section{SEISMOSTRATIGRAPHY}

A Quaternary seismostratigraphic sequence of five units has been recognized in the northwest Gulf and the Estuary of the St. Lawrence, including Saguenay Fjord (Table I). On the basis of their geometry and distribution, acoustic character, and inferred or sampled composition, the units are interpreted to represent a succession of 1) glacial ice-contact, 2) glacial marine proximal, 3) glacial marine distal, 4) glacial fluviodeltaic, and 5) postglacial estuarine/marine environments, during deglaciation from the Late Wisconsinan maximum subsequent to $14 \mathrm{ka} \mathrm{BP}$ (Syvistki and Praeg, 1989).

The upper four of these units are recognized overlying bedrock in and adjacent to the North Channel trough; unit 1 could be present beneath the largely unpenetrated trough axis. Units 2 and 3 dominate the sequence, in thicknesses up to at least $290 \mathrm{~m}$. Unit 4 occurs locally in thicknesses over $30 \mathrm{~m}$; unit 5 forms a surficial cover up to $30 \mathrm{~m}$ thick. Samples have previously been collected and described from units 3 and 5 in the study area (Loring and Nota, 1973; d'Anglejan and Brisebois, $1974 ; 1978)$. The seismostratigraphic sequence can be related to extensive Late Wisconsinan sediments described from surficial mapping and borings of the south shore (Lee, 1962) and of the north shore valleys (Chagnon, 1969; Rondot, 1974; Poulin, 1976), which consist of discontinuous tills and outwash deposits, overlain by thick clays of the Goldthwait Sea, capped by fluvial/deltaic sands and gravels which grade into less extensive modern alluvium; raised Holocene marine deposits are also recognized (Dionne, 1988).

Pre-Late Wisconsinan sediments have been recognized locally on the northwest shore of Île aux Coudres, where Late Wisconsinan till (locally overlain by Goldthwait Sea littoral sediments) overlies fluvial sands containing a peat layer which yields radiocarbon dates on wood of Middle Wisconsinan age; sands immediately beneath the till are glaciotectonically deformed (Brodeur and Allard, 1985). Glacigenic and nonglacigenic sands and muds underlying the fluvial sands could date back to the last interglacial (Occhietti and Clet, 1989; Clet et al., 1991). Seismic profiles recently collected from the area show stratified sediments filling a bedrock valley up to $160 \mathrm{~m}$ below sea level; an erosional surface is recognized within the sequence at $<10 \mathrm{~m}$ depth, and samples of the upper interval indicate marine muds (Todd et al., 1991). Since our seismic

TABLE I

Summary of regional Quaternary seismostratigraphy in the northwest Gulf and Estuary of the St. Lawrence, including Saguenay Fjord (after Syvitski and Praeg, 1989)

\begin{tabular}{|c|c|c|c|c|c|}
\hline Unit & Acoustic Attributes* & Geometry & $\begin{array}{l}\text { Maximum } \\
\text { Thickness } \\
\text { (m) }\end{array}$ & $\begin{array}{l}\text { Inferred** } \\
\text { Composition }\end{array}$ & Interpretation \\
\hline \multirow{3}{*}{5} & weak reflectors/low tone & basinal & 60 & mud & \multirow{3}{*}{$\begin{array}{c}\text { postglacial } \\
\text { estuarine/marine } \\
\text { muds, sands \& gravels } \\
\end{array}$} \\
\hline & no reflectors/high tone & bedforms & 20 & sand & \\
\hline & low-high sidescan tone & veneers & $<1$ & sands and gravels & \\
\hline 4 & $\begin{array}{l}\text { primarily strong reflectors } \\
\text { (ponded); intervals of no } \\
\text { reflectors/high tone }\end{array}$ & lobes & 100 & $\begin{array}{c}\text { primarily coarse; } \\
\text { texturally variable } \\
\text { layers } \\
\end{array}$ & $\begin{array}{c}\text { deglacial } \\
\text { fluvio-deltaic lobes } \\
\text { (slides \& turbidity currents) }\end{array}$ \\
\hline 3 & $\begin{array}{l}\text { weak reflectors/low tone } \\
\text { (reflectors conformable) }\end{array}$ & onlapping & 500 & $\begin{array}{l}\text { mud } \\
\text { ('Leda clay') }\end{array}$ & $\begin{array}{c}\text { glacial marine distal } \\
\text { (deposition from meltwater plumes) }\end{array}$ \\
\hline \multirow[t]{3}{*}{2} & & & & & $\begin{array}{c}\text { glacial marine proximal } \\
\text { (deposition near ice-margin sources) }\end{array}$ \\
\hline & $\begin{array}{l}\text { strong-weak reflectors } \\
\text { (conformable) }\end{array}$ & draped & 20 & fine-coarse layers & rapidly retreating margin \\
\hline & $\begin{array}{l}\text { strong reflectors, bounding } \\
\text { irregular intervals of no } \\
\text { reflectors; in places ponded }\end{array}$ & wedge-shaped & 160 & primarily coarse & stable margin \\
\hline 1 & $\begin{array}{l}\text { low-high tone, } \\
\text { occasional reflectors }\end{array}$ & $\begin{array}{l}\text { complex- } \\
\text { irregular } \\
\text { (constructional } \\
\text { or basin-fill) } \\
\end{array}$ & $>200$ & texturally variable & $\begin{array}{c}\text { glacial ice-contact } \\
\text { (deposited or deformed) }\end{array}$ \\
\hline
\end{tabular}


units 2 and 3 form a continuous (weakly stratified) sequence identified as Goldthwait Sea muds (see below), any pre-Late Wisconsinan sediments would be expected to underlie icecontact unit 1, or to be potential components of it in the case of glacially deformed sediments (Table I). However, unit 1 is not recognized beneath units 2 and 3 on our seismic profiles adjacent to Île aux Coudres, nor are older units, although resolution is poor in the deeper parts of the section (Fig. 3).

\section{UNIT 1 (GLACIAL ICE-CONTACT SEDIMENTS)}

Ice-contact refers to sediment deposited or deformed by glacial ice (Gilbert, 1985; Syvitski and Praeg, 1989). Unit 1 in the Laurentian Channel, and in Saguenay Fjord, onlaps the respective bedrock troughs and is thin or absent on the steep walls in a basin-fill geometry, possibly indicative of deformed sediments (Table I). In similar fashion, unit 1 may also be present beneath units 2 and 3 along parts of the unpenetrated axis of the North Channel trough. The presence of ice-contact sediments elsewhere in the middle estuary is indicated by hydrosonde seismic profiles, supplemented by boreholes, described by Simard (1971) from the south side of the estuary between Île aux Coudres and Québec (Fig. 1). Thick glacial clays (correlative to units 2 and 3 ) are underlain by an irregular layer of "sand, gravel or boulders" up to $30 \mathrm{~m}$ thick. The 'irregular' geometry of the coarse lower layer is consistent with constructional unit 1 geometries (Table I). Related sediments on the shores of the estuary are often recognized as irregular in nature (e.g. tills and ice-contact deposits of the Saint-Antonin and Saint-Narcisse Moraines - Lee, 1962; Rondot, 1974), although they typically include or consist of finer textures (e.g. tills and diamictons of Îles aux Coudres - Brodeur and Allard, 1985).

\section{UNITS 2 AND 3 (GLACIAL MARINE SEDIMENTS)}

These units represent glacial marine sediment deposited in the higher relative sea levels of the Goldthwait Sea: unit 2 is argued to represent deposition proximal to ice-margin sediment sources, and unit 3 distal deposition from meltwater plumes (Syvitski and Praeg, 1989).

Unit 2 occurs in both draped and wedge-shaped geometries (Table I). A 10-20 m thick interval with a draped geometry is recognized overlying bedrock beneath onlapping unit 3 reflectors on the trough wall between Baie-Saint-Paul (Fig. $3 a, c)$ and La Malbaie (Fig. 5a,b; see also Fig. 8a). The draped interval lacks the medium to strong internal reflectors typical elsewhere (Table I) and is of low tone, suggesting a homogenous, finegrained composition similar to overlying unit 3 (mud). In contrast, a strengthening of unit 3 reflectors towards the entrance to Saguenay Fjord suggests a lateral transition to a coarsegrained accumulation of unit 2 (Fig. $6 \mathrm{~d}, \mathrm{e}$ ). A wedge-shaped accumulation of unit 2 up to $260 \mathrm{~m}$ or more thick is recognized on the seaward side of the sill at the Saguenay entrance, in part distally transitional to unit 3 in the lower estuary (Syvitski and Praeg, 1989, 1990).

Unit 3 is typically characterized by weak or no reflectors and low tone, characteristics which allow recognition of the basal reflector through thicknesses over $250 \mathrm{~m}$ (Fig. 4a), and through up to 10 seabed multiples (e.g. Figs. 3a,c, 5). Reflectors, including some stronger events, are conformable where present, and onlap unit 2 or the walls of the bedrock trough (Figs. 3c,5,6a). An interval of stronger reflectors is persistent across the top of the unit in the île aux Lièvres basin (Figs. 6b,c), thicker along the south side due to subsequent erosion (see below). The reflectors indicate a depositional axis to the south of the modern one (Fig. 6b), and descend away from the Saguenay entrance (cf. Figs. $6 \mathrm{~b}$ and 6c; also see reflectors in Fig. 6d).

Unit 3 is correlative to extensive raised marine clays mapped along the shores of the St. Lawrence Estuary and Gulf as 'Leda clay' (Dawson, 1893), or as clays of the Goldthwait, Champlain or Laflamme seas (Dionne, 1977). These sediments are distinctive bluish-grey, stiff, massive to laminated clays to silts (e.g. Gadd, 1971; Dredge, 1983), which boreholes show are up to $40 \mathrm{~m}$ thick at Rivière Ouelle (d'Anglejan, 1981), $90 \mathrm{~m}$ thick at Baie-Saint-Paul (Chagnon, 1969) and can exceed $230 \mathrm{~m}$ in thickness in other north shore valleys (see Dredge, 1983). The presence of the clays at or beneath the floor of the middle estuary has been documented from core samples and boreholes (Lee, 1962; Simard, 1971; Loring and Nota, 1973; d'Anglejan and Brisebois, 1974; 1978).

Units 2 and 3 together volumetrically dominate sediments in the middle estuary. Combined thicknesses increase from $100 \mathrm{~m}$ to over $200 \mathrm{~m}$ along the trough axis adjacent to BaieSaint-Paul, and thicknesses over $250 \mathrm{~m}$ (290 m maximum) are measured along the trough walls seaward to La Malbaie (Fig. 4a). Axial thicknesses must exceed $300 \mathrm{~m}$ along parts, if not most, of the trough. Unit 3 is absent across the sill at the entrance to the Saguenay, where unit 2 thickens to at least $260 \mathrm{~m}$; unit 3 thickens to $167 \mathrm{~m}$ in the lower estuary as unit 2 thins, and to $500 \mathrm{~m}$ in Saguenay Fjord (Syvitski and Praeg, 1989).

\section{UNIT 3 SURFACE UNCONFORMITY}

The surface of unit 3 has been eroded to produce an angular unconformity in the subsurface or at the estuary floor across much of the middle estuary. In most places the unconformity is smooth, and underlying reflectors are truncated at low angles (Figs. 5c, 6b,c). Such relationships are observed not only near bathymetric highs, such as English Bank (Fig. 5c) or île aux Lièvres (Fig. 6b, left-hand side), but in the Île aux Coudres basin to depths of at least $50 \mathrm{~m}$, and along the axis of the île aux Lièvres basin to depths over $150 \mathrm{~m}$ (Fig. 6c). The present form of the Île aux Lièvres basin is a reflection of the unconformity surface: reflector truncations indicate greater erosion of unit 3 (at least $15 \mathrm{~m}$ ) along both the south side and the present axis of the basin (Fig. 6b,c); the axial erosion is responsible for the present basin axis (and depositional axis for estuarine mud) close to the north wall of the North Channel (cf. Figs. 2 and 7).

The surface unconformity displays irregular relief in shallow depths adjacent to La Malbaie, and upstream from Baie-SaintPaul (Fig. 7). At La Malbaie, apparently incised relief of up to 5 m occurs in the subsurface, below muds of unit 5 , to depths below sea level of $50 \mathrm{~m}$ (Fig. 5a,b); at Baie-Saint-Paul, irregular relief of up to $3 \mathrm{~m}$ occurs over part of the area where unit 3 is exposed at the estuary floor, to depths of $30 \mathrm{~m}$ (Fig. 3a,c). 
FIGURE 5. Interpreted seismic reflection profiles from the La Malbaie area $(a$ and $b=1986$ air gun; $c=1974$ sparker, from d'Anglejan and Brisebois, 1978; ct. Fig. 2): a) transverse to longitudinal profile across/along the north wall of the buried trough; the lower draped interval (unit 2) may continue down the steep $\left(8^{\circ}\right)$ wall of the trough below onlapping reflectors (unit 3); an irregular surface unconformity above $50 \mathrm{~m}$ below sea level (cf. Fig. 7 for distribution) is overlain by estuarine mud (unit 5), which has been disturbed by an adjacent mass flow from La Malbaie (cf. Fig. 7); b) transverse profile across the south wall of the trough; note the lower draped interval (unit 2) continues down the steep $\left(10^{\circ}\right)$ trough wall beneath onlapping unit 3 reflectors; the irregular surface unconformity is overlain by estuarine mud (unit 5), disturbed as above; $c$ ) longitudinal profile along the south wall of the trough (gradients up to $13^{\circ}$ ); onlapping unit 3 reflectors with a smooth surface unconformity, overlain by estuarine muds. $B R=$ basal reflector bedrock. Vertical scales based on an assumed velocity of $1.5 \mathrm{~km} / \mathrm{s}$.

Interprétation des profils de sismique réflexion de la région de $L a$ Malbaie ( $a$ et $b$ : profils par canon

à air de 1986; c: profil "sparker" de 1974, de d'Anglejan et Brisebois, 1978; voir fig. 2). a) Profils transversal et longitudinal de la paroi nord de la fosse enfouie; l'intervalle inférieur de recouvrement (unité $n^{\circ} 2$ ) semble se poursuivre vers le bas de la paroi abrupte $\left(8^{\circ}\right)$ sous des réflecteurs de chevauchement (unité $n^{\circ} 3$ ); une surface de discordance irrégulière au-dessus de $50 \mathrm{~m}$ sous le niveau de la mer (voir fig. 7) est recouverte d'une couche d'argiles estuariennes (unité $n^{\circ} 5$ ) déformées par un glissement adjacent en provenance de La Malbaie (voir fig. 7). b) Profil transversal du mur sud de la fosse; noter que

Exposed relief at the top of unit 3 is also recognized on pinger profiles across the crest of English Bank, above ca. $25 \mathrm{~m}$ depth (Fig. 7), bounded by stepped relief that might represent terraces along the north side of the Bank.

Sidescan sonar imagery across the area of exposed unit 3 between Baie-Saint-Paul and Île aux Coudres shows a system of closely spaced lineations, of negligible relief, interpreted as truncated bedding planes (Fig. $3 a, b)$. The lineations occur both where the surface of unit 3 is smooth, and where it has up to $3 \mathrm{~m}$ relief (Fig. 7, inset A). Where the seabed is irregular, the lineations appear to be superimposed on and subparallel to the longer-wavelength relief. Similar fine, low-relief lineations have been recognized at the surface of eroded Goldthwait and Champlain sea clays elsewhere, both visually and on sidescan imagery (Hart, 1987; B. Long, pers. comm., 1989).

\section{UNIT 4 (DEGLACIAL FLUVIO-DELTAIC SEDIMENT)}

Unit 4 corresponds to coarse-grained lobes overlying the surface of unit 3, emplaced during expansion of fluvio-deltaic systems as glacial ice withdrew from contact with the
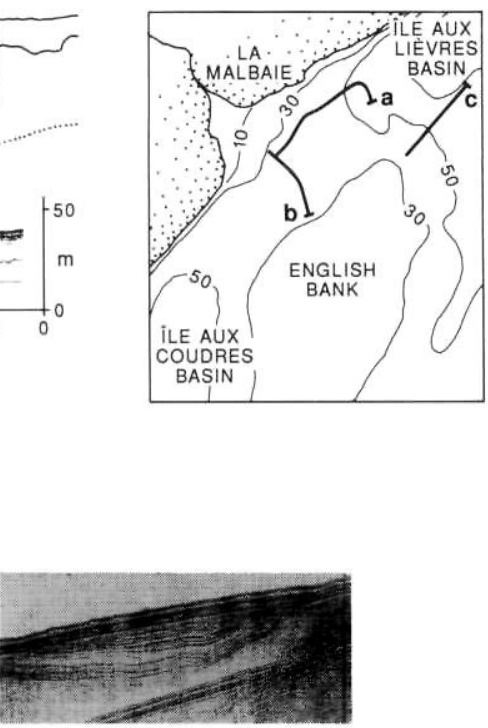

C

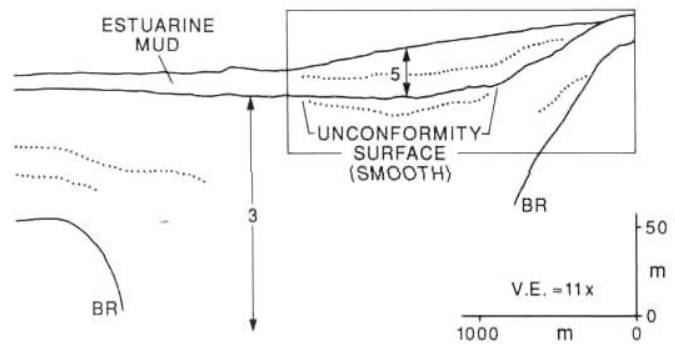

l'intervalle inférieur de recouvrement se poursuit vers le bas de la parol abrupte $\left(10^{\circ}\right)$ de la fosse, sous les réflecteurs de chevauchement de l'unité $n^{\circ} 3$; la surface de discordance irrégulière est surmontée par les argiles estuariennes déformées de l'unité $n^{\circ}$ 5. c) Profil longitudinal le long de la paroi sud de la fosse (pente jusqu'à $13^{\circ}$ ) réflecteurs de chevauchement de l'unité $n^{\circ} 3$ avec surface de discordance unie, recouverte de boues estuariennes. $B R=$ réflecteurs de base/socle rocheux. Échelles verticales fondées sur une vitesse nominale de $1,5 \mathrm{~km} / \mathrm{s}$.

Goldthwait Sea (Syvitski and Praeg, 1989). In the lower estuary lobes of unit 4 extend from the transverse valleys of the north shore (Fig. 1).

In the North Channel, two lobes of unit 4 over $30 \mathrm{~m}$ thick overlie the surface of unit 3, apparently conformably, on the north and south sides of the île aux Coudres basin (Fig. 7; see insets A and $B$ ). A lobe extends from Baie-Saint-Paul on the north side of the basin (Fig. 3a), indicating a source in the valley to the north (Fig. 7). A second, larger lobe on the south side of the basin to seaward includes baselapping reflectors with a prograding bedding style, indicating a southern source (Fig. 8; d'Anglejan and Brisebois, 1978). Glacial fluvio-deltaic sands overlie glacial marine clays in the valleys of the north shore (Chagnon, 1969; Rondot, 1974; Poulin, 1976), and along much of the south shore (Lee, 1962).

The generally weak reflectors and low tone of the lobes (Figs. $3 \mathrm{a}, 8$ ) are in contrast to the unit elsewhere (Table I), and suggest a more homogenous composition; the lobes are not muddy, however, as they afford no high-frequency penetration. The lobe of unit 4 on the south side of the basin is capped by 
FIGURE 6. Interpreted seismic reflection profiles from the Île aux Lièvres basin $(\mathrm{a}=1972$ pinger profile; $b$ to $e=1974$ sparker profiles; $c f$. Fig. 2): a) transverse profile showing draped unit 2 and onlapping unit 3 reflectors across a bedrock high marking the south side of the buried trough (cf. Fig. 4; from d'Anglejan and Brisebois, 1974); estuarine muds (unit 5) have been disturbed by a slide along the north wall (cf. Fig. 7); b) transverse profile showing the south wall of the buried trough (gradient up to $5^{\circ}$ ); unit 3 includes an upper interval of strong reflectors, truncated by a smooth unconformity recording at least $15 \mathrm{~m}$ of erosion; discontinuous sediments with wavy relief are suggestive of sand bedforms (unit 5 ), buried beneath estuarine muds (unit 5) disturbed by mass flow along the north wall (cf. Fig. 7); c) longitudinal profile showing a smooth unit 3 surface unconformity overlain by sediment with wavy relief suggestive of sand bedforms (unit 5 ), buried by unit 5 estuarine mud (from d'Anglejan and Brisebois, 1978); d) and e) longitudinal profile showing unit 3 reflectors rising and strengthening towards the entrance to the Saguenay, indicating a lateral transition to an ice-proximal sediment source (unit 2); the south wall of the buried trough is visible. $\mathrm{BR}=$ basal reflector/bedrock. Vertical scales based on an assumed velocity of $1.5 \mathrm{~km} / \mathrm{s}$.

Interprétation des profils de sismique réflexion du bassin de l'île aux Lièvres (a) profil "pinger" de 1972; b à e) profils "sparker" de 1974; voir fig. 2). a) Profil transversal montrant les réflecteurs de l'intervalle du recouvrement de l'unité $n^{\circ} 2$ et les réflecteurs de chevau-

chement de l'unité $n^{\circ} 3$ traversant la crête rocheuse qui caractérise le côté sud de la fosse enfouie (voir fig. 4 de d'Anglejan et Brisebois, 1974); les argiles estuariennes (unité $n^{\circ} 5$ ) ont été déformées par un glissement le long de la paroi nord (voir fig. 7). b) Profil transversal montrant la paroi sud de la fosse (pente atteignant $5^{\circ}$ ); l'unité $n^{\circ} 3$ comprend un intervalle supérieur d'intenses réflecteurs tronqués par une surface de discordance unie, indiquant une action érosive sur au moins $15 \mathrm{~m}$; des sédiments discontinus, à la topographie ondulante et rappelant des dunes de sable (unité $n^{\circ} 5$ ), sont enfouies sous les argiles estuariennes (unité $n^{\circ} 5$ ) déformées par un glissement le long

sand waves, superimposed on a more reflective surface (Fig. 8a). The reflective surface might be a gravel lag developed at the top of unit 4 , or it might represent compact, less sandy sediments.

\section{UNIT 5 (ESTUARINE MUDS, SANDS AND GRAVELS)}

Unit 5 corresponds to both muds and sandy/gravelly sediments (Table I), which form the estuary floor almost every- where and reflect the establishment of postglacial sedimentation patterns associated with lowered relative sea levels and ablated ice sheets (Syvitski and Praeg, 1989). In the middle estuary unit 5 includes estuarine muds (d'Anglejan and Brisebois, 1974), sand with bedforms (d'Anglejan, 1971), and sandy/gravelly surficial veneers (d'Anglejan and Brisebois, 1978; Loring and Nota, 1973), which unconformably overlie the surfaces of units 3 and 4 (Fig. 7). 


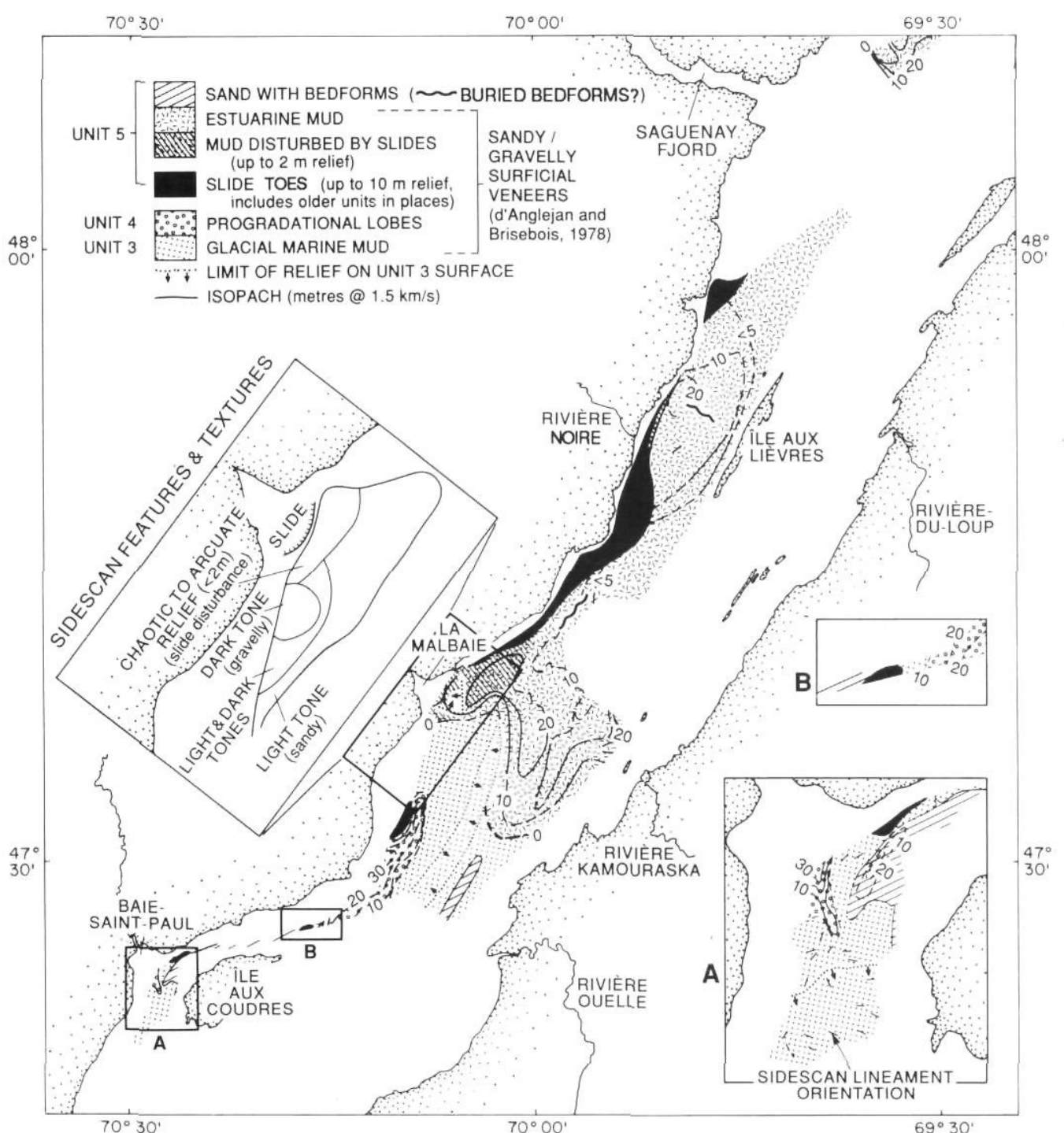

FIGURE 7. Thickness and character of units 5 and 4 , and areas of apparent exposure of underlying unit 3 (surface unconformity). Estuarine mud thicknesses seaward from Saguenay Fjord from Syvitski and Praeg (1990).

Épaisseur et nature des unités $n^{\text {os }}$ 5 et 4 et zones d'affleurement apparent de la surface discordante de l'unité $n^{\circ} 3$ sous-jacente. Épaisseurs des argiles estuariennes du fjord du Saguenay vers la mer, d'après Syvitski et Praeg (1990).

Estuarine mud

This facies is characterized by low tone, and by a general lack of stratification (Fig. 6a,b), although a single internal reflector is recognized locally off La Malbaie (Fig. 5a,c). The mud occurs seaward from La Malbaie, both in the île aux Lièvres basin and on the south side of the estuary, in thicknesses locally up to $30 \mathrm{~m}$ (Fig. 7). The limit of the facies in the île aux Lièvres basin is uncertain as seismic resolution there is limited to about $5 \mathrm{~m}$ (cf. Figs. 6d, 7); it is absent across the sill at the entrance to the Saguenay. This distribution concurs with that shown by d'Anglejan and Brisebois (1974, Fig. 14), save that the mud does not extend upstream from La Malbaie (Fig. 7). Pinger records used in this area by d'Anglejan and Brisebois (1974) were penetrating the clays of unit 3 , which are exposed at the estuary floor (Fig. 7).

The mud facies has a complex basinal geometry, which shows a relationship to adjacent fluvial discharges (Fig. 7). Maximum thicknesses $>20 \mathrm{~m}$ occur adjacent to, and downstream from, Rivière Noire and Rivière Malbaie on the north shore, and Rivière Kamouraska on the south shore. The accumulation off La Malbaie extends across the estuary to the South Channel, towards the outlet of Rivière Ouelle. Maximum thicknesses in the Île aux Lièvres basin do not correspond to max- imum water depths; thus the accumulation off Rivière Noire forms part of a gentle sill between two $>100$ m deep sub-basins (cf. Figs. 2 and 7).

Cores up to $6.5 \mathrm{~m}$ long have been collected from the estuarine mud in the île aux Lièvres basin (d'Anglejan and Brisebois, 1978). A surface veneer of mixed pelites (gravel, sand and mud) overlies thick uniform bluish-grey muds lacking gravel. These muds contain brackish estuarine salinities, foraminiferal species known to exist in the lower estuary and Gulf of St. Lawrence, and alternating layers of silty and less silty mud indicating regular variation in current intensity during deposition (d'Anglejan and Brisebois, 1978).

\section{Sand with bedforms}

This facies occurs upstream from La Malbaie (Fig. 7); it may also be present on part of the sill at the entrance to the Saguenay. Sand bedforms were recognized by d'Anglejan (1971) on the floor of the Île aux Coudres basin between Cap aux Oies and Baie-Saint-Paul, as well as upstream in the North Channel between Île aux Coudres and Île d'Orléans (Fig. 1a). In the Île aux Coudres basin, pinger profiles showed generally symmetrical bedforms up to $12 \mathrm{~m}$ high and up to $120 \mathrm{~m}$ in wavelength, in depths up to $60 \mathrm{~m}$, and suggested the presence 
FIGURE 8. Interpreted acoustic transects (1986 air gun seismic reflection profiles and sidescan sonar imagery; cf. Fig. 2) from the lower île aux Coudres basin: a) longitudinal transect across the south wall of the buried trough; a lower thin $(10 \mathrm{~m}$ ) draped interval (unit 2) may extend down the trough wall beneath onlapping unit 3 reflectors; a unit 4 lobe on the south side of the basin (cf. Fig. 7) contains downlapping reflectors indicating northward progradation; these glacial/ deglacial sediments are overlain by sand bedforms (unit 5), and by a slide lobe from the south side of the basin (cf. Fig. 7); b) longitudinal profile showing unit 3 overlain by unit 4 lobe with downlapping reflectors as above; slide sediments from the north wall of the North Channel (cf. Fig. 7) appear to be associated with deformation of underlying unit 3 reflectors. $B R=$ basal reflector/ bedrock. Vertical scales based on an assumed velocity of $1.5 \mathrm{~km} / \mathrm{s}$.
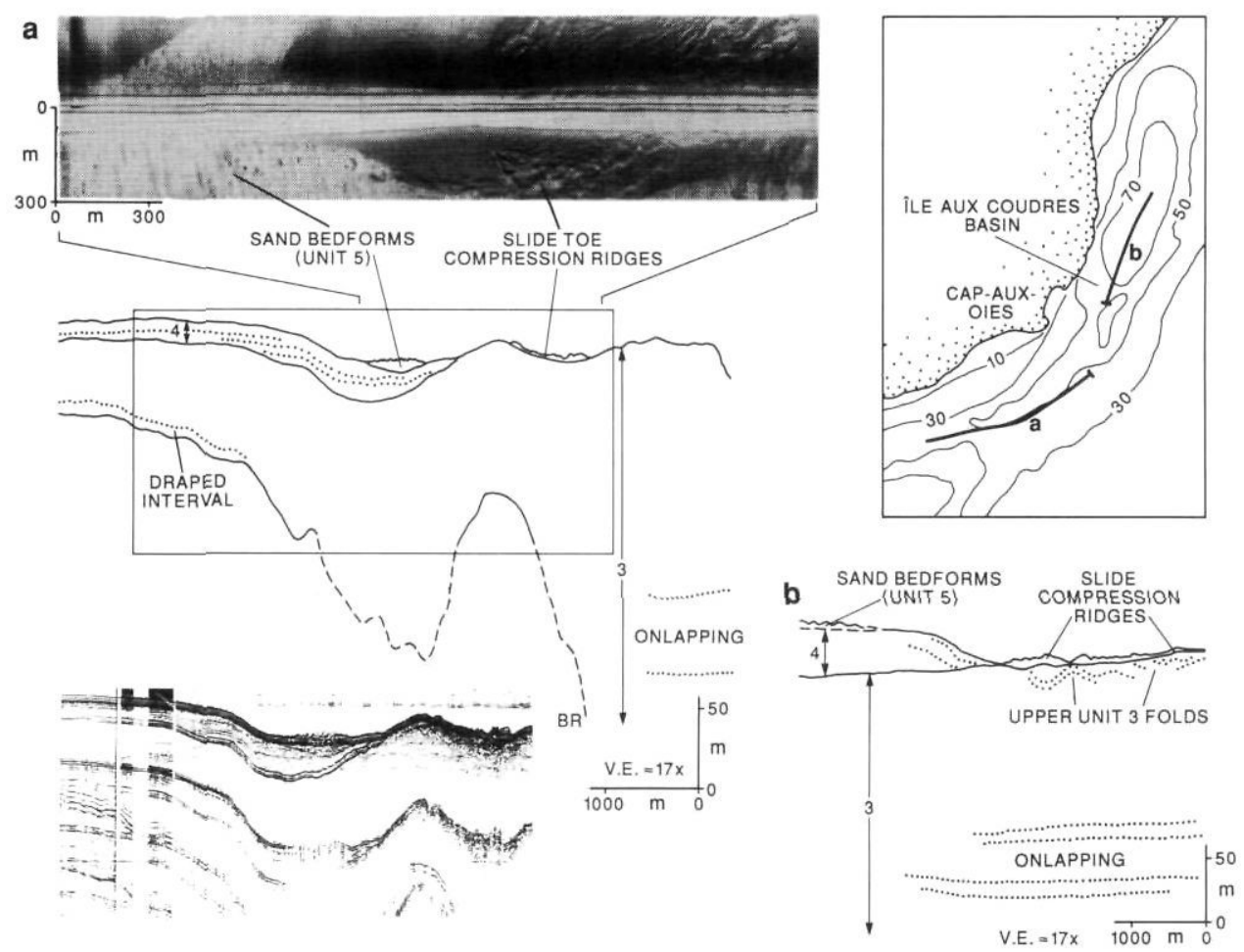

Interprétation des profils acoustiques (profils de sismique réflexion par canon à air de 1986 et relevés par sonar à balayage latéral; voir la fig. 2) du bassin inférieur de l'île aux Coudres. a) Profil longitudinal de la paroi sud de la fosse; un mince intervalle inférieur $(10 \mathrm{~m})$ de recouvrement (unité $n^{\circ}$ 2) semble se poursuivre vers le bas de la paroi sous les réflecteurs de chevauchement de l'unité $n^{\circ} 3$; un lobe de l'unité $n^{\circ} 4$ dans la partie sud du bassin (voir fig. 7) renferme des réflecteurs de chevauchement indicatifs d'une progradation vers le nord; ces sédiments glaciaires sont surmontés de dunes de sable

of symmetrical sub-surface crests. Monahan (1976) examined these features using sidescan sonar images and samples, and reported that small-scale (1-2 m amplitude) ripples were present on the surfaces of larger sand waves, the waves were slightly asymmetric in varying directions, and the sand was superimposed on more reflective relict clays (correlative to unit 3).

Our data shows that sand with bedforms forms a discontinuous cover across the surfaces of units 3 and 4 in the Île aux Coudres basin (Fig. 7). The sand appears acoustically homogenous and of medium tone. It is generally less than $10 \mathrm{~m}$ thick, except between île aux Coudres and Baie-Saint-Paul where a lens up to $22 \mathrm{~m}$ thick is observed along the south side of the basin, capped by sand waves up to $10 \mathrm{~m}$ high (Figs. 3b, 7). A $4.65 \mathrm{~m}$ long piston core from this lens, collected in 1986 at $64 \mathrm{~m}$ depth (Praeg et al., 1987), consists of massive, wellsorted, medium to coarse grained sand with occasional pebbles, composed of subangular to subrounded quartz, feldspar, mafic and rock grains. Seabed samples of similar texture and composition have been described from this area by d'Anglejan (1971) and Monahan (1976).

Buried sand bedforms are suggested by sparker records from the Île aux Lièvres basin (Fig. 7; d'Anglejan and Brisebois, 1978). At two locations, acoustically homogeneous sediment with wavy relief unconformably overlies unit 3 , and is overlain (unité $n^{\circ} 5$ ) et par un lobe de glissement en provenance du sud du bassin (voir fig. 7). b) Profil longitudinal montrant l'unité $n^{\circ} 3$ surmontée par un lobe de l'unité $n^{\circ} 4$ renfermant des réflecteurs de chevauchement; les sédiments liés à des glissements le long de la paroi nord du chenal du Nord (voir fig. 7) semblent associés à la déformation des réflecteurs de l'unité $n^{\circ} 3$ sous-jacente. $B R=$ réflecteurs de base/ socle rocheux. Échelles verticales fondées sur une vitesse nominale de $1,5 \mathrm{~km} / \mathrm{s}$.

by estuarine mud (Fig. 6b,c). The wavy relief has amplitudes of 2-3 m and wavelengths of 200-300 $\mathrm{m}$ at the seaward of the two occurences (Fig. 6b), and amplitudes up to $10 \mathrm{~m}$ and wavelengths of 1000-1500 m at the upstream occurrence (Fig. 6c).

\section{Sandy/gravelly surficial veneers}

The distribution of surficial sediments across the middle estuary (d'Anglejan and Brisebois, 1978; Loring and Nota, 1973) bears only partial relation to the surficial distribution of seismic units shown in Figure 7. Core samples adjacent to La Malbaie (d'Anglejan and Brisebois, 1978), and sidescan sonar imagery, indicate surficial veneers of sandy to gravelly sediments.

High-resolution seismic profiles adjacent to La Malbaie suggest unit 5 muds thin and the underlying surface of unit 3 is exposed (Fig. 7). However, the area is associated with variable sidescan reflectivities (Fig. 7, inset): a zone of high reflectivity (dark tone) corresponds to sampled gravel and/or Goldthwait Sea clays (unit 3), while a zone of low reflectivity (light tone) corresponds to sandy samples. Zones of both mixed and low reflectivity extend seaward across the surface of estuarine muds (Fig. 7); samples indicate the estuary floor in this area is a mixture of sand and mud (Loring and Nota, 1973; d'Anglejan and Brisebois, 1978). Cores show that a surface layer of brownish-grey mixed pelites a few centimetres thick overlies 
$10-30 \mathrm{~cm}$ of coarse sand to pebbles in a mixed pelite matrix, which abruptly overlies uniform bluish-grey estuarine muds (d'Anglejan and Brisebois, 1978). The upper layer corresponds to the sandy sediments observed on sidescan images. Samples to seaward indicate a general fining of surficial sediments with depth, to mud in the deepest parts of the îles aux Lièvres basin (Loring and Nota, 1973).

The surface of unit 3 also appears to be exposed adjacent to Baie-Saint-Paul, where sidescan images show high reflectivity and truncated unit 3 bedding planes (Fig. 3a). However, samples consist largely of gravel (d'Anglejan and Brisebois, 1978). The high reflectivity may be partly due to gravel, but the exposed bedding planes demonstrate that any gravel layer is thin or discontinuous.

\section{SLIDES}

Acoustically unstratified sediment bodies with irregular relief record subaqueous mass displacement, primarily along the steep north wall of the North Channel (Fig. 7). Their relief and geometry suggests they are compressive slide toes, generated by tensional failure of Quaternary sediments farther up the north wall, similar to sidewall failures observed in fjords (Syvitski et al., 1987b).

In the Île aux Lièvres basin, slide toes form a largely continuous feature along the base of the north wall (Fig. 7), that includes remoulded estuarine mud (Fig. 6b). Surface relief varies from up to $10 \mathrm{~m}$ (Fig. 6a), to less than $2 \mathrm{~m}$ but raised up to $7 \mathrm{~m}$ above the adjacent mud surface (Fig. 6b). Acoustic disturbance of mud adjacent to the slide is recognized in the form of a weakening or loss of subbottom reflectors, in association with intermittent seabed relief of up to $2 \mathrm{~m}$ (Figs. 6a,7). Off La Malbaie, sidescan imagery shows that the mud surface in part of the disturbed zone closest to the slide is characterized by chaotic to arcuate relief (Fig. 7 , inset).

In the île aux Coudres basin, slides are observed in two places along the north side of the basin, and locally on the south side (Fig. 7). The slides appear to consist of displaced sediment, rather than remoulded material (Fig. 8). They overlie the surface of unit 3 in thicknesses up to $15 \mathrm{~m}$, and sidescan imagery across the one on the southern side of the basin shows subparallel arcuate relief suggestive of compressive ridges (Fig. 8a). Beneath the slide off Cap aux Oies, folds are observed in the upper part of unit 3 which are unrelated to deeper bedding styles (Fig. 8b), and appear to be the result of compression related to emplacement of overlying or adjacent slide material. The northern two slides may be part of a continuous feature along the base of the north wall seaward of BaieSaint-Paul, similar to the Île aux Lièvres basin.

\section{INTERPRETED LATE QUATERNARY DEPOSITIONAL AND EROSIONAL EVENTS}

No absolute dates are available from the seismostratigraphic units in the middle estuary. However, identification of unit 3 as Goldthwait Sea muds implies that units 2-5 are of Late Wisconsinan to Holocene age. Reconstructions of the Late Wisconsinan deglaciation are available from terrestrial lithoand chronostratigraphic studies (e.g. Dyke and Prest, 1987;
Fig. 1a), as are relative sea level histories subsequent to glacial withdrawal (Dionne, 1988; Fig. 1b). Using these as a framework, and drawing on previous stratigraphic studies in the middle estuary (d'Anglejan, 1990), it is possible to discuss a series of glacial marine to estuarine depositional and erosional events subsequent to the withdrawal of glacial ice ca. $13 \mathrm{ka} \mathrm{BP.}$

\section{GLACIAL MARINE BASIN-FILLING}

Withdrawal of glacial ice from the present middle estuary resulted in the exposure of a deep marine embayment, flanked by sediment generating ice-masses (Fig. 1). Goldthwait Sea levels up to $200 \mathrm{~m}$ above present (Rondot, 1974), added to present depths to bedrock of at least $350 \mathrm{~m}$ (Fig. 4b), correspond to paleo-depths of at least $550 \mathrm{~m}$. The North Channel trough was rapidly filled by over $290 \mathrm{~m}$ of glacial marine sediment.

\section{Calving bay migration?}

An initial episode of ice-proximal sedimentation is suggested by the lowermost draped interval of unit 2 (Figs. 3b, 5b); draped unit 2 geometries elsewhere (Table I) are argued to record sedimentation in association with a rapidly retreating ice margin (Syvitski and Praeg, 1989). This interval may therefore record the postulated migration of a calving margin across the middle estuary (LaSalle et al., 1977; Chauvin et al., 1985) between 13 and $12 \mathrm{ka} \mathrm{BP}$ (Fig. 1). The rate of calving bay extension across the middle estuary has been calculated at either $650 \mathrm{~m}$ or $235 \mathrm{~m}$ per year, depending on whether the older or younger of two available radiocarbon dates are used to fix the commencement of the marine invasion, which reached Québec by $12.4 \mathrm{ka} \mathrm{BP}$ (Parent and Occhietti, 1988). At these rates, the calving margin would have transgressed the $100 \mathrm{~km}$ of the North Channel between the Saguenay and Baie-Saint-Paul in either 150 or 430 years. For a typical $15 \mathrm{~m}$ of draped unit 2, this would correspond to a sedimentation rate of either 10 or $3.5 \mathrm{~cm} / \mathrm{a}$.

\section{Stable ice-margins}

Ice-distal hemipelagic deposition in the Goldthwait Sea is recorded by thick onlapping unit 3 muds overlying draped unit 2 (e.g. Figs. 3c, 5b) or bedrock. A coarser-grained, proximal source (unit 2) for the onlapping muds is suggested by reflectors rising and becoming stronger towards the sill separating the North and Laurentian Channels at the entrance to Saguenay Fjord (Fig. 6d). An ice-proximal source at the entrance to the Saguenay is also indicated for the lower estuary, by a wedge-shaped accumulation of unit 2 (distally transitional to unit 3) beneath the seaward side of the sill (Syvitski and Praeg, 1989). The seismostratigraphic sequences in the lower and middle estuary are therefore considered to be contemporaneous, deposited in association with a stable Laurentide ice-margin at the Saguenay entrance between ca. 13 to 11 ka BP (Fig. 1a).

The sill separating the ille aux Coudres and île aux Lièvres basins (Fig. 2) has been suggested to record deposition from an ice lobe in the La Malbaie valley (Poulin, 1976). The sill is underlain by at least $260 \mathrm{~m}$ of unit 3 muds, which also overlie a bedrock ridge beneath adjacent English Bank (Figs. 5b, 4). Considering the onlapping character of unit 3 , the presence 
of the sill could indicate underlying relief; either a bedrock sill, or an ice-marginal accumulation similar to that at the Saguenay entrance. An accumulation is not present adjacent to the valley of Baie-Saint-Paul, where the trough axis is observed (Fig. 3). Ice-proximal accumulations may be confined to the valleys, which were arms of the Goldthwait Sea in contact with Laurentide ice until at least 12 ka BP (Fig. 1; Rondot, 1974; Poulin, 1976). Ice-proximal sources along the south shore may also have been important, prior to $12.5 \mathrm{ka} \mathrm{BP}$ during the formation of the Saint-Antonin Moraine (Fig. 1; Lee, 1962).

The lateral strengthening of reflectors towards the Saguenay extends to the top of the sediment sequence (Fig. 6d), implying the proximity of an ice-margin sediment source throughout the episode of glacial marine deposition. Laurentide ice margins retreated rapidly from the middle estuary drainage basins subsequent to ca. $11 \mathrm{ka} \mathrm{BP} \mathrm{(Fig.} \mathrm{1),} \mathrm{and}$ while marine waters remained in contact with the Laurentide ice Sheet via the Laflamme Sea occupying the Saguenay region, as well as the Champlain Sea to the west, the volume of ice-distal sediment subsequently deposited in the middle estuary would appear to have been greatly reduced.

The onlapping geometry of unit 3 muds is argued to reflect the importance of surface currents in association with meltwater and sediment discharge (Syvitski and Praeg, 1989); the conformable character of reflectors suggests low bottom currents during deposition, possibly enhanced by high sedimentation rates. Axial deposition of $250 \mathrm{~m}$ of sediment (Fig. 4a) between 13 and $11 \mathrm{ka} \mathrm{BP}$ would corresponds to a rate of $12.5 \mathrm{~cm} / \mathrm{a}$. This compares to rates of $7.5 \mathrm{~cm} / \mathrm{a}$ indicated for Champlain Sea marine clays and silts, deposited $\approx 100 \mathrm{~km}$ west of Québec between 10.8 and $10.0 \mathrm{ka}$ BP (Parent and Occhietti, 1988), and is within the same order of magnitude as rates calculated above for underlying draped unit 2 . Sedimentation rates are partly a reflection of basin size; greater thicknesses of unit 3 were deposited in the smaller basin of the Saguenay (500 m maximum), while lesser thicknesses accumulated in the larger lower estuary (167 m maximum; Syvitski and Praeg, 1989).

\section{MARGINAL DEGLACIAL FLUVIO-DELTAIC INPUT}

A combination of ice-margin retreat and lowering of relative sea levels resulted in withdrawal of glacial ice from contact with the Goldthwait Sea (Fig. 1). Large quantities of material were supplied to fluvial systems, some of which was transported offshore as unit 4. Laurentide ice remained in contact with the Goldthwait Sea in the transverse valleys of the north shore until at least $12 \mathrm{ka} \mathrm{BP}$, and the valleys would have received glacial discharge until the withdrawal of ice from their drainage basins soon after $11 \mathrm{ka} \mathrm{BP}$ (Fig. 1a). Appalachian ice had already withdrawn from the southern shore of the Goldthwait Sea by $12 \mathrm{ka} \mathrm{BP}$, and was almost entirely ablated by $11 \mathrm{ka} \mathrm{BP}$ (Fig. 1a). A large volume of meltwater and fluvio-deltaic sediment would thus have been supplied to the Goldthwait Sea shores during a relatively brief period, from the south and then the north, during most of which glacial ice at the entrance to the Saguenay was still directly supplying sediment to the marine waters (Fig. 1).
Unit 4 in the Île aux Coudres basin has well-defined, apparently conformable contacts with underlying unit 3 (Figs. $3 a, 8$ ), implying that glacial marine sedimentation had largely ceased at these locations when the fluvio-deltaic lobes were emplaced. The seabed sill separating the île aux Coudres and île aux Lièvres basins could have been influential in separating areas distal and proximal to a glacial marine source at the Saguenay. The limited offshore extent of unit 4 along the north shore (Fig. 7) might reflect a relatively brief period of sediment supply into the valleys (Fig. 1a). Widespread drainage along the south shore is indicated by the extent of onshore fluvio-deltaic deposits (Lee, 1962). However, the southern source of unit 4 is puzzling, as English Bank constitutes a barrier to sediment transfer from the south shore into the Île aux Coudres basin (Fig. 2). The extent of unit 4 along the south side of the middle estuary is unknown, and additional work in this area is clearly important.

\section{EROSIONAL EPISODE - LOWERING SEA LEVELS (AND GLACIAL-LAKE FLOODS?)}

Relative sea level reconstructions suggest the Goldthwait Sea episode ended early in the Holocene; sea levels on the south shore of the middle estuary fell rapidly to within $20 \mathrm{~m}$ of present by ca. 9 ka BP (Fig. 1b). The 100 m summit of Île aux Coudres was exposed by $9.8 \mathrm{ka} \mathrm{BP}$, and sea levels were about $85 \mathrm{~m}$ above present by $9.5 \mathrm{ka}$ (Brodeur and Allard, 1985). Fossil faunas indicate the retreating estuarine salt wedge had reached Québec by 9.3 ka (Parent and Occhietti, 1988).

A period of erosional conditions subsequent to glacial marine deposition is recorded by an angular unconformity at the surface of unit 3 (Figs. 5c, 6b,c). There is no clear evidence of erosion of unit 4 , but the apparently conformable contacts between units 3 and 4 (Figs. 3a, 8 ) suggest that erosion of unit 3 post-dates the marginal input of unit 4 .

A smooth unconformity surface over much of the study area suggests erosion by currents. In a general way, this must reflect increasing energy levels at the estuary floor in association with lowering relative sea levels. However, erosion along the axis of the Île aux Lièvres basin (at least $15 \mathrm{~m}$, to depths over $150 \mathrm{~m}$; Fig. 6b) points to exceptionally strong, deep currents. High-magnitude drainages of glacial Lake Agassiz into the Great Lakes-Ottawa River system, and through the St. Lawrence Lowlands, represent a possible source. Lake Agassiz drained eastwards between 10.8-10.0 ka BP and 9.5-8.0 ka BP, during which times flow through the St. Lawrence Lowlands more than doubled (Teller, 1987). The drainage included flood discharges of up to $4000 \mathrm{~km}^{3}$ at up to $200,000 \mathrm{~m}^{3} / \mathrm{s}$, as little as a few years in duration, which would have increased flow by up to four times (Teller and Thorliefson, 1987). Relative sea levels in the middle estuary were still at least $70 \mathrm{~m}$ higher than present during the first episode (Dionne, 1988), but less than this during the second (Brodeur and Allard, 1985; Dionne, 1988); relative sea levels on the south shore were as little as $3 \mathrm{~m}$ above present by $8 \mathrm{ka}$ BP (Dionne, 1988). The transfer of such large volumes of water into or through the middle estuary, during the second, younger episode in particular, would have reinforced erosional conditions due to falling relative sea levels, which culminated in a lowstand ca. 7-6 ka BP (Fig. 1b). 
An irregular unconformity surface above depths of 25-50 m suggests depth-controlled erosion, although the nature of the $<5 \mathrm{~m}$ relief is uncertain. Relief to depths of $50 \mathrm{~m}$ off La Malbaie (Figs. 5a, 7) could in part record erosion during transfer of sediment from the adjacent delta, possibly to form sand waves (see below). However, this cannot account for irregular relief to depths of 25-30 m on the English Bank and upstream from Baie-Saint-Paul (Figs. 3a, 7). Stratigraphic evidence from the south shore of the middle estuary indicates that relative sea levels were at least $5 \mathrm{~m}$ lower than present between ca. 7-6 ka BP (Fig. 1b; Dionne, 1988), and possibly $10 \mathrm{~m}$ lower based on geomorphic evidence from Baie de Sainte-Anne, off Montmagny (Fig. 1a; d'Anglejan, 1981). This lowstand may have extended even deeper, exposing or bringing near to sea level depths of $25-30 \mathrm{~m}$.

In the lower estuary, a Holocene relative sea level lowstand of 35-40 m was proposed for the Rimouski shelf (Fig. 1b), to account for cored Goldthwait Sea clays sharply overlain by sandy sediments that fine upwards to the estuary floor (Silverberg, 1978); basal dates on the sand of ca. 5.2-5.4 ka BP provide a minimum age for any preceding erosion. A ridge of well-sorted, rounded pebbles was observed in $40 \mathrm{~m}$ depth during a submersible dive off Pointe-des-Monts in the lower estuary (Syvitski et al., 1983), which might represent a submerged beach line. In Baie des Chaleurs, geomorphic evidence indicates Holocene relative sea levels at least $30 \mathrm{~m}$ and as much as $70 \mathrm{~m}$ below present (Syvitski et al., 1987a). The possibility of a relative sea level lowstand of such magnitude in the St. Lawrence Estuary clearly merits further investigation.

\section{GENESIS OF SAND BEDFORMS}

The source of the sand in the middle estuary has long been a question (see Monahan, 1976). There is no evidence for coarse-grained glacial deposits at or near most of the estuary floor (Fig. 7), other than unit 2 sediments near the Saguenay entrance (Fig. 6e; Syvitski and Praeg, 1990), and the underlying glacial marine clays of unit 3 represent a poor source of sand (d'Anglejan and Brisebois, 1978). The sand could be derived from fluvial erosion of glacial deposits on the shores (d'Anglejan, 1971), in particular during postglacial emergence and fluvial downcutting; this is recognized to have been significant in the Baie-Saint-Paul and La Malbaie valleys (Rondot, 1974; Poulin, 1976; Dionne, 1977). Enhanced early postglacial erosion and transport corresponds to the paraglacial cycle (Church and Ryder, 1972; Jackson et al., 1982), augmented here by lowered base levels. The potential significance of paraglacial processes is indirectly illustrated by aeolian reworking of glacial marine littoral deposits, which resulted in the formation of a variety of dune forms in the St. Lawrence Lowlands between ca. 10.8 to $9.5 \mathrm{ka} \mathrm{BP}$ (David, 1987).

The presence of buried sand bedforms in the île aux Lièvres basin (Figs. 6b,c, 7) would confirm that sand in the middle estuary is largely relict from an earlier Holocene input of sediment, subsequent to the erosion of unit 3 , and prior to the accumulation of estuarine mud. Such an input would form part of a progressive reduction in energy levels in the estuary. On the Rimouski shelf of the lower estuary (Fig. 1a), cored sandy sediments fining upwards above Goldthwait Sea clays record such a progressive reduction in energy levels since at least ca.
5.2-5.4 ka BP, possibly due to rising relative sea levels (Silverberg, 1978). It is obviously important to try to confirm the presence of sand bedforms in the subsurface of the middle estuary by sampling.

It may be that surficial bedforms in the middle estuary are also relict, or at least palimpsest. D'Anglejan (1971) noted that local asymmetry of large-scale bedforms in the l̂le aux Coudres basin was contrary to the direction which would be expected from present tidal current strengths. Monahan (1976) repeatedly surveyed smaller scale bedforms in one part of the area east of île aux Coudres, in depths of 13-19 m, at least twice a day for two weeks, and found no detectable migration or change of shape on sidescan sonar images although the survey covered "virtually every stage of the tidal cycle". He suggested the bedforms only moved during a part of the year. An alternative explanation is that they, and many other large-scale bedforms in the study area in depths of up to $65 \mathrm{~m}$, do not move at all, but are simply reworked by modern current activity. Sand waves that do not appear to move are also reported in the estuary of eastern Long Island Sound (Fenster et al., 1990), and may similarly reflect a reduction in estuarine energy levels during the Holocene.

\section{DEPOSITION OF ESTUARINE MUD AND OVERLYING SANDY/GRAVELLY VENEERS}

Sea levels in the middle estuary rose 8 to $10 \mathrm{~m}$ above present subsequent to $6 \mathrm{ka} B P$, then fell to near present levels by ca. 3 ka BP (Dionne, 1988). Estuarine deposition subsequent to early postglacial erosion and sand bedform generation is recorded by unit 5 muds, which appear to primarily represent deposition from adjacent fluvial sources (Fig. 7). Cores collected from the muds indicate regular estuarine deposition in the absence of either bioturbation or ice-rafting (d'Anglejan and Brisebois, 1978). The muds may partly reflect enhanced paraglacial fluvial sediment supply, as envisaged for the sand bedforms, but under low energy conditions that permitted deposition of fine sediments.

Both a primarily local fluvial source for the muds, and paraglacially enhanced fluvial supply, are corroborated by hydrological data for the Rivière Malbaie, which indicate a present annual sediment delivery of $8 \times 10^{4} \mathrm{~m}^{3} / \mathrm{a}$ from a drainage area of $1682 \mathrm{~km}^{2}$ (Slivitzky, 1978). If this rate is applied to the accumulation of estuarine mud adjacent to La Malbaie (Fig. 7), then: considering only the area within the North Channel and bounded by the $10 \mathrm{~m}$ isopach, and assuming an average thickness of $15 \mathrm{~m}$ for sediments between the $10-20 \mathrm{~m}$ isopachs, and $25 \mathrm{~m}$ for sediments within the $20 \mathrm{~m}$ isopach, the resulting $8.7 \times 10^{8} \mathrm{~m}^{3}$ of mud could be deposited in $10.9 \mathrm{ka}$ at modern rates. Assuming the given rate is representative of modern conditions, this suggests that sediment delivery from the small rivers bordering the estuary is within the same order of magnitude as that required to accomodate the observed sediment thicknesses; but that higher rates earlier in the Holocene and/or additional sources would be required to deposit the mud within the Holocene.

Cores indicate that estuarine mud deposition abruptly gave way to higher energy conditions: an initial period of ice-rafting (mixed gravel, sand and mud) and a subsequent period of 
bioturbation (surficial mixed sand and mud) (d'Anglejan and Brisebois, 1978). The ages and origins of these changes in energy conditions and sediment supply in the middle estuary remain unknown. A lack of ${ }^{137} \mathrm{Cs}$ activity in the surficial sands and muds, in contrast to south shore tidal flat muds, indicates that these events predate the atomic age and present net deposition is insignificant (d'Anglejan and Brisebois, 1978). The modern estuarine regime is dominated by export of suspended sediment into the lower Estuary and the Gulf of St. Lawrence, with accumulation of muds $<0.5 \mathrm{~m}$ thick in shallow depressions in the North and South Channels in the area of the turbidity maximum above Île aux Coudres, and a seasonal cycle of deposition and erosion on mudflats and marshes (d'Anglejan, 1990).

\section{MASS DISPLACEMENT}

A debris flow lobe on the north shore of the middle estuary opposite Île aux Coudres has been attributed to the 1663 earthquake (Quilliam and Allard, 1989), which is also known to have initiated a large failure in Saguenay Fjord (Chagnon and Locat, 1988). The Charlevoix seismic zone has experienced at least five earthquakes of magnitude $>6$ since 1663 (Adams and Basham, 1989), and probabilistic peak ground velocities are among the highest in Canada at $>0.32 \mathrm{~g}$ (Basham et al., 1985), so recent seismicity represents a likely initiating mechanism for slides in the middle estuary. Spontaneous failure of 'sensitive' glacial marine clays exposed above sea level (Chagnon and Locat, 1988) may also have contributed to mass displacement along the steep north wall of the North Channel (Fig. 7). Slide toes in the North Channel involve, and therefore at least partly postdate, estuarine muds of unit 5 (Figs. 6, 7). However, there is no reason to infer a single event; mass displacement may have been continuous since the end of the Goldthwait Sea episode.

\section{CONCLUSIONS}

The Late Quaternary features and history of the North Channel of the middle estuary are schematically summarized in Figure 9.

The North Channel is the surface expression of a buried trough at least $350 \mathrm{~m}$ deep; it represents the extension of the glacially modified Laurentian bedrock trough some $100 \mathrm{~km}$ above the Saguenay, to the upstream limit of a large-scale zone of glacial erosion along troughs. Fluvial characteristics at the head of the trough adjacent to Baie-Saint-Paul (axial gradient $0.7^{\circ}, \mathrm{v}$-shaped channels) might represent preserved pre-glacial relief.

The upper four of five regional Quaternary seismostratigraphic units (Table I) are recognized in and adjacent to the North Channel trough; they are correlated with Late Wisconsinan sediments on the shores of the estuary, and interpreted to record glacial marine to estuarine deposition and erosion subsequent to the withdrawal of glacial ice after ca. $13 \mathrm{ka} \mathrm{BP}$. Lower ice-contact sediments (regional unit 1) or older sediments might also be present, beneath the largely unpenetrated trough axis, and elsewhere in the middle estuary (Simard, 1971).

The sequence is volumetrically dominated by glacial marine sediments (units 2 and $3,>290$ m thick), which were deposited in the up to $200 \mathrm{~m}$ deeper relative levels of the Goldthwait Sea, in a marine embayment at least $550 \mathrm{~m}$ deep. An initial period of sedimentation along a retreating ice-margin is suggested by a lower draped interval (unit 2, <20 $\mathrm{m}$ thick); glacial ice is thought to have withdrawn along a calving margin between ca. 13-12.4 ka (Chauvin et al., 1985; Parent and Occhietti, 1988). A subsequent period of distal basin-filling from meltwater plumes is recorded by thick onlapping clays (unit 3, >290 m thick); an ice-proximal source for the clays is indicated by a lateral transition (stronger reflectors) to a coarse-grained

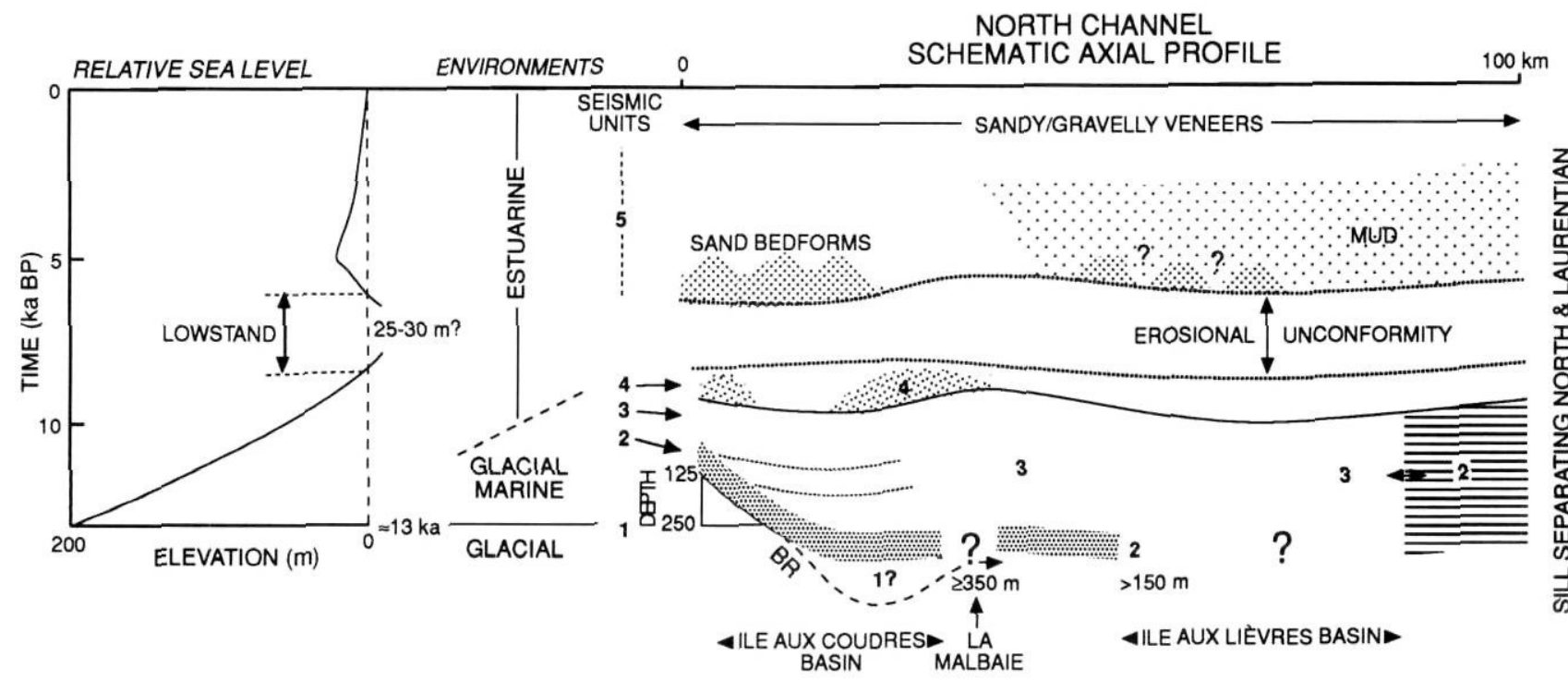

FIGURE 9. Schematic axial profile of the North Channel summarizing the distribution and relations of the seismostratigraphic units, and the related glacial/sea level history.
Profil schématique de l'axe du chenal du Nord résumant la répartition des unités sismostratigraphiques ainsi que leurs relations et l'évolution correspondante du milieu glaciaire, glacio-marin et marin. 
sediment wedge beneath the sill separating the North and Laurentian channels at the Saguenay entrance (unit 2, $\geqslant 260 \mathrm{~m}$ thick; Syvitski and Praeg, 1989; 1990). A stable ice-margin at the Saguenay entrance between ca. 13-11 ka BP supplied sediment to both the middle and lower estuary.

Marginal input consequent on separation of glacial ice from the Goldthwait Sea is indicated by two lobes (unit $4,>30 \mathrm{~m}$ thick) that overlie glacial marine clays (unit 3) on either side of the Île aux Coudres basin; the northern lobe extends from Baie-Saint-Paul, where glacial fluvio-deltaic sediment was supplied sometime between $12 \mathrm{ka}$ and soon after $11 \mathrm{ka} \mathrm{BP}$; the source of the prograding southern lobe is unclear, although fluvio-deltaic sediment was deposited along the south shore.

The majority of sediments filling the North Channel trough were deposited prior to the Holocene, within a few thousands years of glacial withdrawal. A subsequent period of erosion in association with lowering relative sea levels is recorded by an angular unconformity at the top of the glacial marine sediments (unit 3). Erosion by strong currents (at least $15 \mathrm{~m}$ ) is indicated by a smooth unconformity surface that extends to depths $>150 \mathrm{~m}$; high-magnitude floods from drainage of glacial Lake Agassiz passed through the St. Lawrence Lowlands between 10.8-10.0 ka BP and 9.5-8.0 ka BP (Teller, 1987). An irregular unconformity surface above depths of $25-50 \mathrm{~m}$ could relate to a relative sea level lowstand; relative sea levels in the middle estuary were at least $5 \mathrm{~m}$ below present between ca. 7-6 ka BP (Dionne, 1988).

A return to depositional conditions is recorded by estuarine sands, gravels and muds (unit $5, \leqslant 30 \mathrm{~m}$ thick) overlying the unconformity surface. Sand bedforms occur at the estuary floor, and possibly buried beneath estuarine muds; buried bedforms would confirm an early Holocene source for the sand, and a subsequent reduction in estuarine energy levels; surface bedforms, which do not appear to move (Monahan, 1976), may also be relict or palimpsest. Greatest thicknesses of estuarine mud correspond to adjacent fluvial sources; modern suspended sediment delivery is of the order of magnitude required to accomodate the observed thickness, assuming higher rates earlier in the Holocene. A sandy to gravelly surficial veneer forms the estuary floor in most places; it records a period of ice-rafting followed by present coarse lag conditions (d'Anglejan and Brisebois, 1978).

Slide toes record downslope transfer of sediment and disturbance of estuarine muds (unit 5) and glacial marine clays (unit 3) along the north, and locally the south, walls of the North Channel; the 1663 earthquake represents a likely initiating event, although failure may have been active throughout the postglacial period.

\section{ACKNOWLEDGMENTS}

The surveys were conducted from the MV Metredia in 1972, the CSS Sackville in 1974 and the CSS Dawson in 1986/88, and we thank the ships' contingent of each vessel for their cooperation. Drs. F. Hein, C. F. M. Lewis, J. Locat and B. Long each provided useful discussions or reference material. The manuscript was critically read by Drs. S. Occhietti, J. Shaw, and $\mathrm{B}$. Todd, and greatly improved as a result.

\section{REFERENCES}

Adams, J. and Basham, P., 1989. The seismicity and seismotectonics of Canada east of the Cordillera. Geoscience Canada, 16(1): 3-16.

d'Anglejan, B. F., 1971. Submarine sand dunes in the St. Lawrence Estuary. Canadian Journal of Earth Sciences, 8: 1480-1486.

- 1981. Évolution post-glaciaire et sédiments récents de la plate-forme infra-littorale, Baie de Sainte-Anne, Estuaire du Saint-Laurent, Québec. Géographie physique et Quaternaire, 35(2): 253-260.

- 1990. Recent sediments and sediment transport processes in the St. Lawrence Estuary, p. 109-129. In M. I. El-Sabh and N. Silverberg, eds., Oceanography of a Large-Scale Estuarine System: The St. Lawrence. Coastal and Estuarine Studies, Vol. 39, Springer-Verlag, New York.

d'Anglejan, B. F. and Brisebois, M., 1974. First subbotoom acoustic reflector and thickness of recent sediments in the middle estuary of the St. Lawrence River. Canadian Journal of Earth Sciences, 11: 232-245.

1978. Recent sediments of the St. Lawrence middie estuary. Journal of Sedimentary Petrology, 48: 951-964.

Avramtchev, L. (compiler), 1985. Carte géologique du Québec. Ministère de l'Énergie et des Ressources, Direction générale de l'Exploration géologique et minérale, Carte no. 2000 du DV 84-02.

Basham, P. W., Weichert, D. H., Anglin, F. M. and Berry, M. J., 1985. New probabilistic strong seismic ground motion maps of Canada. Bulletin of the Seismological Society of America, 75: 563-595.

Bostock, H. S., 1970. Physiographic regions of Canada. Geological Survey of Canada, Map 1254A.

Brodeur, D. and Allard, M., 1985. Stratigraphie et Quaternaire de l'île aux Coudres, estuaire moyen du Saint-Laurent, Québec. Géographie physique et Quaternaire, 34(2): 183-197.

Chagnon, J.-Y., 1969. Study of erosion phenomena and unconsolidated deposits in Baie-Saint-Paul - Saint-Urbain area, Charlevoix County. Québec Department of Natural Resources, Special Paper 3: 29 p. + 1 map.

Chagnon, J.-Y. and Locat, J. 1988. The effects of seismic activity on the soils of the Charlevoix area - Québec, Canada, p. 125-136. In M. I. El-Sabh and T. S. Murty, eds., Natural and Man-Made Hazards. D. Reidel Publishing.

Chauvin, L., Martineau, G. and LaSalle, P., 1985. Deglaciation of the lower St. Lawrence Region, Québec, p. 111-123. In H. W. Borns, Jr., P. LaSalle and W. B. Thompson, eds., Late Pleistocene History of Northeastern New England and Adjacent Québec. Geological Society of America, Special Paper 197.

Church, M. and Ryder, J. M., 1972. Paraglacial sedimentation: a consideration of fluvial processes conditioned by glaciation. Geological Society of America Bulletin, 83: 3072-3095.

Clet, M., Occhietti, S. and Hétu, B., 1991. Nouvelles données sur la stratigraphie et les paléoenvironnements de l'île aux Coudres (estuaire moyen du SaintLaurent, Québec). Bulletin d'information de l'Association québécoise pour l'étude du Quaternaire, 17(1): 15.

David, P. P., 1987. The coeval eolian environment of the Champlain Sea episode, p. 291-305. In N. R. Gadd, ed., The Late Quaternary Development of the Champlain Sea Basin. Geological Association of Canada, Special Paper 35.

Dawson, J. W., 1893. The Canadian Ice Age. Dawson Brothers, Montréal, 301 p.

Dionne, J.-C., 1963. Vers une définition plus adéquate de l'estuaire du SaintLaurent. Zeitschrift für Geomorphologie, 7(1): 37-47.

- 1977. La mer de Goldthwait au Québec. Géographie physique et Quaternaire, $31(1-2): 61-80$.

1988. Holocene relative sea-level fluctuations in the St. Lawrence Estuary, Québec, Canada. Quaternary Research, 29: 233-244.

- 1990. Observations sur le niveau marin relatif à l'Holocène, à Rivièredu-Loup, estuaire du Saint-Laurent, Québec. Géographie physique et Quaternaire, 44(1): 43-53.

Dredge, L., 1983. Surficial geology of the Sept-Isles area, Québec north shore. Geological Survey of Canada, Memoir 408, 40 p. 
Dyke, A. S. and Prest, V. K., 1987. Late Wisconsinan and Holocene history of the Laurentide Ice Sheet. In R. J. Fulton and J. T. Andrews, eds., The Laurentide Ice Sheet. Géographie physique et Quaternaire, 41: 237-264 + 4 maps.

El-Sabh, M. I. and Silverberg, N., eds., 1990. Oceanography of a Large-Scale Estuarine System: The St. Lawrence. Coastal and Estuarine Studies, Vol. 39, Springer-Verlag, New York.

Elson, J. A., 1969. Late Quaternary marine submergence of Québec. Revue de géographie de Montréal, 23(3): 247-258.

Fenster, M. S., Fitzgerald, D. M., Bohlen, W. F., Lewis, R. S. and Baldwin, C. T., 1990. Stability of giant sand waves in eastern Long Island Sound, U.S.A. Marine Geology, 91: 207-225.

Gadd, N. R., 1971. Pleistocene geology of the central St. Lawrence Lowland. Geological Survey of Canada, Memoir 359, 153 p.

Gilbert, R., 1985. Quaternary glaciomarine sedimentation interpreted from seismic surveys of fiords on Baffin Island, N.W.T. Arctic, 38(4): 271-280.

Goldthwait, J. W., 1933. The St. Lawrence Lowland, p. 115-153. In N. R. Gadd, ed., Pleistocene Geology of the Central St. Lawrence Lowland. Geological Survey of Canada, Memoir 359.

Hamilton, E. L., 1985. Sound velocity as a function of depth in marine sediments. Journal of the Acoustical Society of America, 78: 1348-1355.

Hardy, L., 1970. Géomorphologie glaciaire et post-glaciaire de St-Siméon à St-François d'Assises (Comtés de Charlevoix Est et de Chicoutimi). M.Sc. thesis, Université Laval, Québec, $112 \mathrm{p}$.

Hart, B. S., 1987. The evolution of the Outardes Estuary. M.Sc. thesis, Université du Québec à Rimouski.

Jackson, Jr., L. E., MacDonald, G. M. and Wilson, M. C., 1982. Paraglacial origin for terraced river sediments in Bow Valley, Alberta. Canadian Journal of Earth Sciences, 19(12): 2219-2231.

LaSalle, P., Martineau, G. and Chauvin, L., 1977. Morphologie, stratigraphie et déglaciation dans la région de Beauce-Monts Notre-Dame - Parc des Laurentides. Ministère des Richesses naturelles, Québec, DPV-516, 74 p.

Lee, H. A., 1962. Surficial geology of Rivière-du-Loup and Trois-Pistoles area, Québec. Geological Survey of Canada, Paper 61-32: 2 p. + map.

Locat, J., 1977. L'émersion des terres dans la région de Baie-des-Sables/TroisPistoles, Québec. Géographie physique et Quaternaire, 31(3-4): 297-306.

Loring, D. H. and Nota, D. J. G., 1973. Morphology and sediments of the Gulf of St. Lawrence. Fisheries Research Board of Canada, Bulletin 182, 147 p.

Lortie, G. and Guilbault, J.- P., 1984. Les diatomées et les foraminifères de sédiments marins post-glaciaires du Bas-Saint-Laurent (Québec): une analyse comparée des assemblages. Naturaliste Canadien, 111: 297-310.

Lowell, T. V., Kite, J. S., Calkin, P. E. and Halter, E. F., 1990. Analysis of smallscale erosional data and a sequence of late Pleistocene flow reversal, northern New England. Geological Society of America Bulletin, 102: 74-85.

Monahan, D., 1976. Morphology and sediments of sand waves in the St. Lawrence Estuary. Maritime Sediments, 12(1): 1-7.

Occhietti, S. and Clet, M., 1989. The last interglacial/glacial group of sediments in the St. Lawrence valley, Québec, Canada. Quaternary International, 3/4: 123-129.

Parent, M. and Occhietti, S., 1988. Late Wisconsinan deglaciation and Champlain Sea invasion in the St. Lawrence valley, Québec. Géographie physique et Quaternaire, 42(3): 215-246.

Poulin, P., 1976. Le complexe morainique de Saint-Narcisse dans le secteur sud de la Rivière Malbaie; interprétation paléoclimatique par l'analyse pollinique. M.Sc. thesis, Département de Géographie, Université Laval, Québec, 83 p.
Praeg, D. B. and Syvitski, J. P. M., 1991. Marine geology of Saguenay Fjord. Geological Survey of Canada, Open File Report 2395, 14 sheets.

Praeg, D. B., Syvitski, J. P. M., Schafer, C. T., Johnston, B. L. and Hackett, D. W., 1987. CSS Dawson 86-016 Cruise Report. Geological Survey of Canada, Open File Report 1412, 44 p.

Quilliam, L. and Allard, M., 1989. Évolution géomorphologique du glissement de terrain et du marais littoral de Saint-Joseph-de-la-Rive, Charlevoix, Québec. Géographie physique et Quaternaire, 43(3): 367-376.

Rondot, J., 1974. L'épisode glaciaire de Saint-Narcisse dans Charlevoix, Québec. Revue de géographie du Montréal, 28(4): 375-388.

Sala, M. and Long, B., 1989. Évolution des structures deltaïques du delta de la rivière Natashquan, Québec. Géographie physique et Quaternaire, 43(3): 311-323.

Santord, B. V., Grant, A. C., Wade, J. A. and Barss, M. S. (compilers), 1979. Geology of Eastern Canada and Adjacent Areas. Geological Survey of Canada, Map 1401A.

Shepard, F. P., 1931. Saint Lawrence (Cabot Strait) submarine trough. Bulletin of the Geological Society of America, 42: 853-864.

Silverberg, N., 1978. Sediments of the Rimouski shelf region, lower St. Lawrence Estuary. Canadian Journal of Earth Sciences, 15: 1724-1736.

Simard, L., 1971. Catalog of St. Lawrence River Soil and Rock Data, First Edition. Department of Transport, Marine Hydraulics Branch, St. Lawrence Ship Channel Division, Engineering Field Investigations Section, Montréal, 2 vol., 339 p., 7 maps.

Slivitzky, M., 1978. Hydrological Atlas of Canada. Surveys and Mapping Branch, Department of Energy, Mines and Resources, Canada.

Sugden, D. E., 1978. Glacial erosion by the Laurentide ice sheet. Journal of Glaciology, 20(83): 367-391.

Syvitski, J. P. M., 1988. Dawson 88-008 Technical Cruise Summary. Geological Survey of Canada, Open File Report 1920, 60 p.

Syvitski, J. P. M., Beattie, D. D., Praeg, D. B. and Schafer, C. T., 1987a. Marine geology of Baie des Chaleurs. Geological Survey of Canada, Open File Report 1375, 5 sheets.

Syvitski, J. P. M., Burrell, D. C. and Skei, J. M., 1987b. Fjords: Processes and Products. Springer-Verlag, New York, 379 p.

Syvitski, J. P. M. and Praeg, D. B., 1989. Quaternary sedimentation in the St. Lawrence Estuary and adjoining areas, eastern Canada: an overview based on high-resolution seismo-stratigraphy. Géographie physique et Quaternaire, 43(3): 291-310.

1990. Quaternary Seismostratigraphy of the Lower St. Lawrence Estuary. Geological Survey of Canada, Open File Report 2230, 10 sheets.

Syvitski, J. P. M., Silverberg, N., Ouellet, G. and Asprey, K. W., 1983. First observations of benthos and seston from a submersible in the lower St. Lawrence Estuary. Géographie physique et Quaternaire, 37(3): 227-240.

Teller, J. T., 1987. Lake Agassiz and its contribution to Flow through the Ottawa-St. Lawrence system, p. 281-289. In N. R. Gadd, ed., The Late Quaternary Development of the Champlain Sea Basin. Geological Association of Canada, Special Paper 35.

Teller, J. T. and Thorleifson, L. H., 1987. Catastrophic flooding into the Great Lakes from Lake Agassiz, p. 121-138. In L. Mayerand and D. Nash, eds., Catastrophic Flooding. Allen and Unwin, Boston, $410 \mathrm{p}$.

Thomas, R. H., 1977. Calving bay dynamics and ice sheet retreat up the St. Lawrence valley system. Géographie physique et Quaternaire, 31(3): 347-356.

Todd, B., Occhietti, S., Burns, R. and Vézina, J., 1991. Profils de sismique réflexion à haute résolution du futur site de forage du Pléistocène de l'île aux Coudres, estuaire du Saint-Laurent. Bulletin d'information de l'Association québécoise pour l'étude du Quaternaire, 17(1): 50. 